Şırnak Üniversitesi

Ilahiyat Fakültesi Dergisi

Sayı 26 Haziran 2021

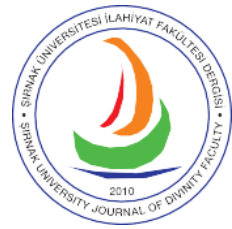

e-ISSN 2667-6575
Şırnak University

Journal of Divinity Faculty

Issue 26 June 2021

\title{
Son Dönem Osmanlı Taşrasında Bir Müderris: İlyas Efendi ve Sicil Dosyası
}

A Mudarris in the Late Ottoman State: Ilyas Efendi and His Registry File

\section{Ahmet BEKEN}

Dr., Çukurova Üniversitesi, İlahiyat Fakültesi, Din Eğitimi Ana Bilim Dalı PhD, Çukurova University, Faculty of Divinity, Department of Religious Education

Adana, Turkey ahmtbeken@gmail.com https://orcid.org/0000-0002-5243-7605

\section{Makale Bilgisi / Article Information}

Makale Türü / Article Types: Araştırma Makalesi / Research Article

Geliş Tarihi / Received: 11 Mart / March 2021

Kabul Tarihi / Accepted: 8 Mayıs / May 2021

Yayın Tarihi / Published: 15 Haziran / June 2021

Sayı / Issue: 26 Sayfa / Pages: 25-52

Atıf / Cite as: Beken, Ahmet. "Son Dönem Osmanlı Taşrasında Bir Müderris: İlyas Efendi ve Sicil Dosyası [A Mudarris in the Late Ottoman State: Ilyas Efendi and His Registry File]". Şırnak Üniversitesi İlahiyat Fakültesi Dergisi - Şırnak University Journal of Divinity Faculty 26 (June 2021), 25-52. https://doi.org/10.35415/sirnakifd.895343

Etik Beyanı / Ethics Declaration: Bu makalede bilimsel araştırma ve yayın etiği ilkelerine riayet edilmiştir. Makale etik izin gerektirmeyen bir çalışma olup en az iki hakem tarafından incelenmiş ve intihal içermediği teyit edilmiştir./ In this article, the principles of scientific research and publication ethics are respected. The article is a study that does not require ethical permission. It has been reviewed by at least two referees and was confirmed that it did not contain plagiarism.

Copyright @ P Published by Şırnak Üniversitesi, İlahiyat Fakültesi / Şırnak, Türkiye (Şırnak University, Faculty of Divinity, Şırnak, 73000 Turkey). 


\section{Özet}

Osmanlı dönemi medreseleri, gerek tedris edilen ilimler ve okutulan kitaplar, gerekse istihdam alanları açısından selefi Selçukluların devamı niteliğindedir. İcâzet/nâme alarak medrese eğitimini tamamlayan talebeler; din görevliliği alanında (müftülük, vaizlik, imamlık), müderrislik ve kadılık gibi mansıplarda istihdam edilmişlerdir. Dolayısıyla medreseler, uzun süre devletin adli, idari, mülki ve eğitimle ilgili kadro ihtiyacını karşılamıştır. Bununla birlikte özellikle Tanzimat Döneminden (1839-1878) sonra açılan yeni eğitim kurumları da sözü edilen alanlarda devletin kadro ihtiyacını karşılamaya başlamış ve hatta ilerleyen zamanlarda medreselerin istihdam alanını daraltmıştır. Ancak medreselerin durumu, müderrislerin hayatı, talebelerin imtihan ve istihdamları gibi konular çoğunlukla bilâd-1 selâse (İstanbul, Bursa ve Edirne) merkezli incelenmiş, bunların taşradaki durumlarıyla ilgili yeterince çalışma yapılmamıştır. Dolayısıyla bu çalışmada, Hatay/Dörtyol müderrisi İlyas Efendi (1873-1956) ve ona ait sicil dosyası özelinde taşradaki bir müderrisin öğrenim hayatı ve imtihan varakası üzerinden istihdamı konu edilmiştir. Çalışmada dokümanlara dayalı veri toplama ve içerik analizini esas alan nitel araştırma yöntemi kullanılmıştır. Bu bağlamda Başbakanlık Osmanlı Arşivinden ve zaman zaman Halep, Adana ve Ankara Vilayet Salnâmeleri ile Maârif Nezâreti Salnâmelerinden istifade edilmiştir. Hâçin'de (Saimbeyli) doğan ve ilk tahsilini doğduğu yerde alan İlyas Efendi, ilmî bir heyet tarafından ehliyet ve liyakatine hükmedilerek müderris olarak atanmıştır. Tanzimat Dönemiyle başlayan eğitimde Batı etkisi ve medrese dışında kurulan yeni eğitim kurumlarıyla eğitimde modernleşme, eğitim sisteminde olduğu gibi medrese mezunlarının istihdamında da birtakım değişmelere ve daralmalara neden olmuştur. Nitekim adli, idari, askeri vs. görevliler, yeni açılan eğitim kurumlarıyla karşılanırken medresenin istihdam alanı çoğunlukla din hizmetlerini ifa edecek görevlilerin ve müderris gibi medrese elemanının yetiştirilmesine hasredilmiştir. İlyas Efendi'nin tahsil hayatı, icâzet metni ve imtihan varakası -Tefsir ve Hadis hariç- öğrenim gördüğü ilimlerden imtihana tabi tutulduğu, Tefsir, Hadis ve Hadis Usulü gibi ilimlerle ilgili de doğrudan soruların yer almadığı görülmektedir. İncelediğimiz belgede İlyas Efendi'nin hangi alan(lar)da ders verdiğiyle ilgili net bilgi bulunmamakla birlikte icâzet ve imtihan varakasından hareketle öncelikle Fıkıh ve Kelâm gibi dinî ilimlerle Arap Dili ve Belagatine yönelik dersler verdiği ileri sürülebilir. Her ne kadar çerçevesi belli standart bir müfredattan bahsetmek zor olsa da İlyas Efendi'ye ait dosyadan hareketle taşra medreselerinde okutulan derslerin/kitapların Osmanlı medreselerinde hemen her dönemde okutulan metinlerle benzerlik gösterdiği, bu yönüyle büyük ölçüde Osmanlı merkez medrese kültürünü devam ettirdiği sonucuna varılabilir. Bunu, icâzet metninde yer alan ulemâ silsilesinden de görmek mümkündür. Bunun yanında Osmanlı Medreseleri ve bunlarla ilgili müfredat incelendiğinde -farklı derecelerde okunmak üzere- Mutavvel, (Molla) Câmî, Mülteka'l-Ebhur, Dürerü'l-Hükkâm, Şerh-i Akâid ve $\hat{I} s \hat{a} g \hat{u} c \hat{\imath}$ 'nin ortak kitaplar olduğuna tesadüf edilmektedir. Okutulan eserler ve istihdamla ilgili uygulamalar göz önüne alındığında taşradaki medreseleri merkezdeki benzerlerinden ayırmanın mümkün olmayacağı sonucuna varılabilir.

Anahtar Kelimeler: Din Eğitimi, Müderris, İlyas Efendi, İcâzet Metni, İmtihan Varakası. 


\section{Summary}

The madrasahs of the Ottoman period are continuations of their predecessors in Seljuks in terms of both the sciences and books taught and employment opportunities. Students, who have completed their madrasah education by getting ijazatnāma/idjāza, were employed as professors and judges or pursued religious careers as muftis, preachers, and imams. Therefore, madrasahs met the juridical, administrative, civilian, and educational staff needs of the state for a long time. In addition, new educational institutions opened especially after the Period of Tanzimat (18391878) met the staff need of the state in the mentioned areas and even narrowed employment areas of madrasahs in later times. However, issues such as the conditions of madrasahs, the lives of mudarrisun, the examination and employment of students were mostly studied with the samples of bilād-ı salāsa (Istanbul, Bursa, and Edirne), and there were not enough studies about the case in rural areas. Therefore, this study discusses the employment of a mudarris in the countryside through his education life and exam papers, in the sample of İlyas Efendi (18731956), the mudarris of Hatay/Dörtyol, and his registry file. In the study, a qualitative research method based on data collection and content analysis of documents was used. In this context, the Ottoman Archive of Prime Ministry, and partially, Haleb, Adana, and Ankara provincial yearbooks/annuals (sālnāma) and National Education Yearbooks were used. Ilyas Efendi, who was born in Hācın (Saimbeyli) and received his first education there, was appointed as a mudarris by a scientific committee by judging his competence and merit. Western influence in education that started with the Tanzimat Period and modernization in education with the establishment of new educational institutions caused some changes and contractions in the employment of madrasah graduates. As a matter of fact, while the need for judicial, administrative, military, etc. officials was met by newly opened educational institutions, employment areas of the madrasah was mostly comprised of officials who would perform religious services and madrasah staff such as mudarrisun. When Ilyas Efendi's education life, ijazatnāma/idjāza texts, and exam document are examined, it is seen that he was tested in the sciences he studied, and there are no direct questions in the disciplines such as Tafsir, Hadith and the Methodology of Hadith. Although there is no clear information about the field(s) in which Ilyas Efendi thaught in the document we examined, it can be argued that he primarily gave lectures on religious disciplines such as Fiqh and Kalam, as well as Arabic Language and Rhetoric, based on the certificate and examination. Although it is difficult to talk about a standard curriculum with a certain framework, it can be concluded from the file belonging to Illyas Efendi that the courses/books taught in the rural madrasahs are similar to the texts taught in the Ottoman madrasahs in almost every period, and in this respect, they continue the Ottoman central madrasah culture to a large extent. It is also possible to see this from the series of scholars in the text of idjāza. In addition, when the Ottoman Madrasahs and their curriculum are examined, common books such as Mutavval, (Molla) Cāmî, Multeka'l-Ebhur, Dureru'l-Hukkām, Şerh-i Akāid and $\hat{I} s \bar{a} g \hat{u} c \hat{\imath}$ (to be taught in different degrees) are encountered. Considering the works taught and the practices related to employment, it can be concluded that it is not possible to distinguish the madrasahs in the rural areas from their counterparts in the urban areas.

Keywords: Religious Education, Mudarris, Ilyas Efendi, Ijazatnāma / Idjāza Text, Exam Document. 


\section{Giriş}

Medrese, İslam dünyasında uzun yıllar orta ve yüksek düzeyde eğitim ve öğretim faaliyetlerinin gerçekleştiği mekân(lar)ın genel adıdır. Karahanlılar (840-1212) ve Gazneliler (963-1186) ile başlayan medrese geleneği Selçuklular (1040-1308), Zengîler (1127-1233), Eyyûbîler (1171-1462), Anadolu Beylikleri (13. yüzyıldan başlayarak Anadolu'nun muhtelif bölgelerinde kurulan Türk beylikleri) ve Memlükler (1250-1517) ile devam etmiş, Osmanlı Devleti'yle (1300-1922) (özellikle Fâtih'in tesis ettiği Sahn-1 Semân ve Kanûnî'nin kurduğu Süleymaniye Medreseleriyle) zirvesini yaşamıştır. Bilhassa II. Meşrutiyet döneminde (19081920) yapılan ıslahatlara rağmen medreseler, varlığını devam ettiremeyerek Tevhîd-i Tedrîsât Kanunuyla (3 Mart 1340/1924) Maarif Vekâleti'ne devredilip kanunun neşredilmesinden kısa bir süre sonra kapatılmıştır. ${ }^{1}$

Medreseler, kapatılıncaya kadar tarihsel süreçte önemli görevler üstlenmiştir. Nitekim medreselerin önemli kuruluş amaçlarından biri, devletin adli, hukuki, idari ve eğitici kadro ihtiyacını karşılamaktır. Dolayısıyla medreselerden mezun olan talebeler, zikri geçen kadroların birinde ya da birkaçında istihdam edilmiştir. Başka bir ifadeyle medrese mezunları özellikle imâm, vâiz, müftü, fakîh, müderris ve kâdı gibi görevler almışlardır. Nitekim Büyük Selçuklular döneminden itibaren medreselerde öğrenim görenlerin dinî hizmet alanlarının yanı sıra hukuk ve devletin mülkî teşkilatında görev aldıkları² ve aynı geleneğin Osmanlı Devletinde de devam ettiği, ulemaya öğretim ve din hizmetlerinin yanında kadılık gibi hukukî görevlerin verildiği, devletin idarî işlerinde görevlendirildikleri bilinmektedir. ${ }^{3}$ Bununla birlikte bilhassa Tanzimat Döneminden itibaren idarî ve hukukî sistemin devamını sağlayacak elemanların yetiştirilmesi amacıyla bu alanlarda yeni öğretim kurumlarının açılması ve Matematik ve tabiî ilimlerin tedrisatının daha da azalarak öğretimin büyük ölçüde dinî ilimlerle sınırlı kalmasıyla medreselerin bu alanlardaki fonksiyonlarında zaman içinde tedricen bir daralmanın olduğu, sonuçta görevlerin genellikle din görevliliği alanıyla sınırlı kaldığı görülmektedir. ${ }^{4}$ Nitekim 1910'dan beri yapılan programlara bakıldığında

1 Mehmet İpşirli, “Medrese” (Osmanlı Dönemi), Türkiye Diyanet Vakfı İslâm Ansiklopedisi (Ankara: TDV Yayinları, 2003), 28/327-333.

2 Mehmet Altay Köymen, Büyük Selçuklu Imparatorluğu Tarihi (Ankara: TTK Basımevi, 1992), 3/355.

3 İsmail Hakkı Uzunçarşıll, Osmanlı Devleti'nin İlmiye Teşkilâtı (Ankara: TTK Basımevi, 1988), 179-180; Zeki Salih Zengin, Tanzimat Dönemi Osmanlı Örgün Eğitim Kurumlarrnda Din Eğitimi ve Öğretimi (1839-1876) (İstanbul: MEB Yayınları, 2004), 107-108.

4 Zengin, Din Eğitimi ve Öğrretimi, 108; Zeki Salih Zengin, II. Meşrutiyette Medreseler ve Din Eğitimi (Ankara: Akçă̆ Yayınları, 2002), 87-88; Yaşar Sarıkaya, "II. Meşrutiyet ve Medreseler: Geleneksel Bir Kurumun 
medreselerin önceden olduğu gibi genel bir eğitim-öğretim kurumu olmayıp müderrislik ile beraber bugünkü manasıyla din görevlisi yetiştiren mesleki ağırlıklı ortaöğretim kurumları olarak görüldüğü anlaşılmaktadır. ${ }^{5}$

Osmanlı Devletinin klasik dönemi özelinde değerlendirilecek olursa öğrenimlerini tamamlayarak medreseden mezun olan talebelerin görevlendirilmelerinin belirli bir usule bağlı olarak yapıldığ1 görülmektedir.6 Buna göre mezun talebeler, "Matlab" (Rûznâme-

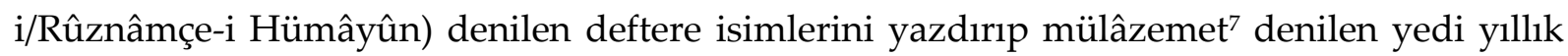
bir staj dönemini (görev bekleme süresini) tamamladıktan sonra imtihana alınmakta, daha sonra aşağı dereceli (40 akçeli ve daha aşağı olan) medreselerden (hâşiye-i tecrîd/yirmili, miftâh/otuzlu) başlamak üzere müderrislik ve kadılık görevlerine atanmaktadır. Sözü edilen geleneksel usulün Tanzimat Döneminden yaklaşık on altı yıl öncesine kadar geçerli olduğu bilinmektedir. Nitekim Ahmed Cevdet Paşa (öl. 1895)'nın verdiği bilgilerden hareketle icâzet alan talebelerin aşağı dereceli medreselerde yedi yıllık mülâzemetten sonra imtihana alındıkları ve başarılı olanların görevlendirildikleri anlaşılmaktadır. ${ }^{8}$

16. yüzyıldan itibaren aşağı dereceli medreselerin müderrisleri müftü, imam-hatip ve müezzinlerin tayinleri kazaskerlerin, yukarı dereceli müderrisler ve kadıların tayinleri ise şeyhülislamın teklifi, sadrazamın arzı ve padişahın onayıyla yapılmaktadır. ${ }^{9}$ Önceki dönemlerde medreselerden mezun olan talebelerden yüksek payeli medreselerde görev almak isteyenlerin, mülâzemet adıyla verilen staj döneminden sonra ruûs ${ }^{10}$ imtihanına

Modernleşme Sürecinde Var Olma Mücadelesi", Dîvân Disiplinlerarası Çalışmalar Dergisi 13/25 (2008), 37-73. Nitekim 1854'te Muallimhâne-i Nüvvâb (1884'ten sonra Mekteb-i Nüvvâb/Kudât adını almıştır)'ın kurulmasıyla medreseler, hukuk ve adalet sahasındaki tekellerini kaybetmişlerdir. Bk. Adem Ölmez, "II. Meşrutiyet Devrinde Osmanlı Medreselerinde Reform Çabaları ve Merkezileşme”, Vakıflar Dergisi 41 (Haziran 2014).

5 Sarıkaya, "II. Meşrutiyet ve Medreseler", 37-73.

6 Daha detaylı bilgi için bk. Ayşe Zişan Furat, “Fetih Sonrasında Osmanlı Eğitim Anlayışının Şekillenişi: Klasik Dönem Müderrislik İmtihanları", Osmanlı'da İlim ve Fikir Dünyası: İstanbul'un Fethinden Süleymaniye Medreselerinin Kuruluşuna Kadar, ed. Ömer Mahir Alper - Müstakim Arıcı (İstanbul: Klasik Yayınları, 2015).

7 Medrese tahsilini bitirip icâzet alanların müderrislik ve kadılık almak için sıra beklemeleri, bu arada meslekî tecrübe kazanıp becerilerini geliştirmeleri ve belirli kontenjanlardan istifade ile göreve başlamalarını ifade etmektedir. Yedi senelik mülâzimlik süresini dolduranlar "ruûs" imtihanına girerlerdi. İmtihanda başarılı olanlar "ibtida-i hâriç ruûsu" ile müderris tayin edilirlerdi. Başarılı olamayanlar ve başarılı olanlardan isteyenler "kaza" mesleğine geçip "kadı" olabiliyorlardı. Bk. Mehmet Zeki Pakalın, Osmanlı Tarih Deyimleri ve Terimleri Sözlü̆g̈ I-III (İstanbul: MEB Basımevi, 1993), 2/611-612; Mehmet İpşirli, “Mülâzemet”, Türkiye Diyanet Vakfi İslâm Ansiklopedisi (İstanbul: TDV Yayınları, 2006), 31/537-539.

8 Ahmed Cevdet Paşa, Târîh-i Cevdet I-XII (Dersaâdet: Matbaa-i Osmâniye, 1301/1884), 12/94-95.

9 Uzunçarşılı, Osmanlı Devleti'nin İlmiye Teşkilâtı, 77, 179.

10 Medrese tahsilini tamamlayıp mülâzim olanlardan imtihanda başarı sağlayanlara verilen beratın adıdır. Başka bir tabirle ruûs, ilmiye teşkilatında göreve başlama işlemi için lazım olan belgeye denirdi. Medrese eğitimini bitirip mülâzim olanlardan yedi senelik mülâzemet süresinden sonra girdikleri ruûs imtihanını başaranlar ruûs alırlardı. Bunlar ibtidâ-i hâric medreselerine tayin edildiklerinden ruûslarına ibtidâ-i hâric ruûsu da 
alınarak başarılı olduktan sonra atamaları yapılmaktadır. Tanzimat Dönemine ait belgelerde ise müderrislik (ruûs) imtihanından bahsedilmekle birlikte mülâzemetten söz edilmemektedir. Yine bu dönemde medrese tahsili yapanların hayatlarına bakıldığında mülâzemet usulünün söz konusu olmadığı anlaşılmaktadır. Başka bir ifadeyle mülâzemet usulü zaman içerisinde bazı değişikliklere uğrayarak devam etmişse de Tanzimat Döneminde bilhassa yeni okulların açılması ve memuriyet sisteminin değişmesiyle ortadan kalkmıştır. ${ }^{11}$

Tanzimat yıllarında da cari olan ruûs imtihanları, II. Abdülhamid döneminin (18761908) başlarında yeniden düzenlenmiştir. Buna göre İstanbul ve Bilâd-ı Selâse' de müderrislik görevi almak isteyenlerin medrese eğitimlerini bitirdikten sonra Ders Vekili'nin başkanlığında toplanan komisyon tarafından yapılacak imtihanda başarılı bulunarak şehadetnâme (diploma) almaya hak kazanmış olmaları gerekir. Ayrıca İstanbul dışındaki medreselerde görev yapanlar ile üzerinde "zeyl meşihatliği (vâizlik görevi)" bulunup İstanbul ruûsu almak isteyenler de bu imtihanlarda başarılı olmak zorundadır. Her sene Recep ayında yapılacak ve her adayın iki defa başvurabilme hakkının olduğu bu imtihanda adaylara, Mutavvel adlı eserin yanında farklı ilimlere dair 40 soru sorulacak ve başarılı kabul edilebilmek için bunlardan en az 21 tanesini doğru cevaplaması istenecektir. Buna göre icâzet alarak öğrenimini tamamlayan aday, görev alanına giren mesleklere genellikle imtihan ile atanmakta ve terfii zaman içerisinde yapılmaktadır. ${ }^{12}$

II. Meşrutiyet döneminde (1908-1920) yapılan çalışmalarda örneğin “Medâris-i İlmiye Nizâmnâmesi"nde (16 Safer 1328/27 Şubat 1910) ise müderrislerin görevlerine atanmalarından önce imtihana tabi tutulmaları öngörülmekte; fakat herhangi bir staj döneminden bahsedilmemektedir. Daha sonra taşra medreseleri için hazırlanan nizâmnâmede aynı hususa işaret edilmekle birlikte yeni düzenlemeler de getirilmiştir. Buna göre müderrisler, yeterlilikleri bakımından derecelere ayrılarak uzun zamandır bu göreve devam edenler birinci, yeni göreve başlayanlar ise ikinci gruba dâhil edilmişlerdir. Mezun olup müderrislik görevi almak isteyenler ise ancak imtihan edildikten sonra durumuna göre bir medreseye tayin edilecek ve daha sonra terfi edecektir. Başka bir ifadeyle bu dönemde

deniyordu. Bu şekilde tayini gerçekleşenler, ibtidâ-i hâric medresesinden sonra sıraları geldikçe yükselerek dâhil ve sahn medreselerine geçerlerdi. Bk. Pakalın, Osmanlı Tarih Deyimleri ve Terimleri Sözlü̆̆̈̈, 3/ 71.

11 Zengin, Din Ĕ̆itimi ve Öğretimi, 108-109; İpşirli, “Mülâzemet”, 31/537-539.

12 Zengin, Din Eğitimi ve Öğretimi, 108; Zeki Salih Zengin, II. Abdülhamit Dönemi Örgün Eğitim Kurumlarında Din Ĕgitimi ve Öğretimi (1876-1908) (Adana: Baki Kitabevi, 2003), 146-147. 
medreselerde tedris edilen din ilimlerinin yine medreselerden yetişmiş müderrisler tarafından okutuldukları ve bunların yeterliklerinin ölçülmesi için bazı imtihanlara tabi tutuldukları anlaşılmaktadır. Medâris-i İlmiye Nizâmnâmesinde medreselerden mezun olanların müderrislik, vaizlik ve müftülük gibi din görevliliklerine, ayrıca askeri birlikler içinde görev yapmak üzere alay müftülüğü ve tabur imamlığı vazifelerine yapılan imtihanlarda başarılı olma şartıyla atanacakları ifade edilmektedir. Fen, Tarih ve Coğrafya gibi yeni konulan derslerde ise şayet müderrislerden o dersi okutabilecek kimse yoksa dışarıdan muallim alınması esası getirilmiştir. ${ }^{13}$

Din eğitimi tarihi kapsamında değerlendirilebilecek olan bu çalışma, Hatay/Dörtyol müderrisi İlyas Efendi ve ona ait sicil dosyası ile sınırlıdır. Dolayısıyla çalışmada İlyas Efendi'ye ait tercüme-i hâl, icâzet metni ve imtihan varakasına odaklanılmaktadır. Dosya, İlyas Efendî’nin resmî olarak müderrisliğe atama belgesi özelliği taşıdığından istihdam açısından da önem arz etmektedir. Bu bağlamda araştırmada eğitici kadroya ve din görevliliğine atanmanın hangi temel şartları gerektirdiği, imtihanda hangi alanlardan soruların yer aldığı, bu sorular ve bunlara verilen cevapların medreselerde okutulan diğer bazı kitaplardaki referansları üzerinde durulmuştur. Tarihi bir vesikadan hareket edildiğinden çalışmada belgelere ve dokümanlara dayalı veri toplama ve analiz tekniği esas alınmıştır. İcâzet metni ele alınırken -ulemâ silsilesi hariç- doğrudan çeviri yapmak yerine daha çok metnin yorumlanması şeklinde bir yol takip edilmiştir. İmtihan varakası ise olduğu gibi tercüme edilip bununla ilgili değerlendirmeler sonrasında yapılmıştır. Osmanlı'nın bilhassa son dönemlerinde yeni eğitim kurumlarıyla birlikte medreseler köylere varıncaya dek açılmaya devam etmiştir. Bununla birlikte çalışmada İlyas Efendi ve ona ait dosya örnekliğinde taşradaki medreseler ve buralardan mezun olan talebenin istihdamına yönelik genel bir perspektif ve mütevazı bir katkı sunulmaya çalışılmıştır. Ancak hem taşradaki medreselerin hem de müderrislerin durumuyla ilgili çalışmaların az, dolayısıyla verilerin yetersiz olması sebebiyle aşırı genellemelerden uzak durulmuştur. Zira taşradaki medreselerin ve talebenin durumuyla ilgili kapsamlı sonuçlara ulaşmak, daha fazla çalışmayı gerektirmektedir.

13 Medaris-i İmiye Nizâmnâmesine Zeyl Olarak Tanzim Olunan Taşra Medâris-i Nizâmnâmesi (TMN), İstanbul: Matbaa-i Amire, 1326/1908, 5-6; Zengin, II. Meşrutiyette Medreseler, 149-152, 162. Ancak islahat çabalarına rağmen yeni medrese düzenlemesinin taşraya pek yayılmadı̆̆ının da belirtilmesi gerekir. Bk. Mustafa Ergün, “II. Meşrutiyet Döneminde Medreselerin Durumu ve Islah Çalışmaları”, Ankara Üniversitesi Dil ve TarihCoğrafya Fakültesi Dergisi 30/1-2 (1979/1982), 59-89. 


\section{Dörtyol Müderrisi İlyas Efendi}

İlyas Efendi (İlyâs b. Halîl el-Kozânî), 1290/1873 yılında Kozan sancağına bağlı Hâçin/Hâcin ${ }^{14}$ (Saimbeyli) kazasına/kasabasına bağlı Kötin/Kandilli köyünde doğmuştur. Babasının ismi Halil olup Paşa Ömerzâde ismiyle meşhurdur. İlk eğitimini ibtidâî mektepten ve civar medreselerden alan İlyas Efendi, köyünün müderrisi Hacı Ahmed Efendi'den, o vefat edince de Hacı Numan Efendi'den ders almıştır. Daha sonra Antakya kazasında15 Zincirli Medresesi müderrisi Kömürçukurlu (?) Hacı Ali Efendi'den ${ }^{16}$ Nahiv, Mantık, Me'âni, Mutavvel, (Molla) Câmî, Mülteka'l-Ebhur, Vaz'iyye, Farsça, Arapça ve Âdâb ${ }^{17}$ dersleri tahsil etmiştir. Hâçin müftüsü Mehmed Sıdkı Efendi'nin Hacı Ali Efendi'den on sene, Osman Efendi'den ise sekiz sene eğitim almasından ${ }^{18}$ hareketle İlyas Efendi'nin de aşağı-yukarı aynı sürede eğitim görerek icâzet aldığg ileri sürülebilir.

Ocaklı köyünde müderris olan Hacı Osman Efendi'den Dürerü'l-Hükkâm, Şerh-i Akâid derslerini tahsil ettikten sonra Kayseri'ye ${ }^{19}$ giderek Boğazlıyan(li) Medresesi'nde Câmi'-i Kebîr müderrisi Hamurculu Osman Efendi'den Fıkıh, Fıkıh Usûlü, Kelâm, Hikmet, Âdâb, Ferâiz, Hadis ve Tefsir derslerini okuyarak 1323/1905 senesinde icâzet almıştır. Yumurtalık müftüsü Eyüb Sabri Efendi'nin 1293/1876 yılında doğduğu Darende'de Rüşdiye Mektebi'nde dört

14 1299/1881, 1309/1892 ve 1318/1900 tarihli Adana vilayeti salnamesinde Haçin kazasında iki, 1308/1891 ve 1312/1894 tarihli salnamelerde ise kasaba merkezinde 20 medrese bilgisi yer almaktadır. Bk. Salnâme-i Vilayet- $i$ Adana, Sene 1299, 87; Salnâme-i Vilayet-i Adana, Sene 1309, 149; Salnâme-i Vilayet-i Adana, Sene 1318, 158; Salnâme-i Vilayet-i Adana, Sene 1308, 136; Salnâme-i Vilayet-i Adana, Sene 1312, 74.

15 1284-1290, 1303, 1305 ve 1306 tarihli Haleb vilayeti salnamelerinde Antakya kazasında beş medrese bulunmaktadır. 1307 tarihli salnamede bu sayı birdir. 1308-1315, 1317-18 ve 1320 tarihli salnamelerde kazada 27 medrese olduğu bilgisi yer almaktadır. 1321-24 ve 1326 tarihli salnamelerde ise bu sayı 30'a çıkmıştır. Bk. Salnâme-i Vilayet-i Haleb, Haleb: Haleb Vilayeti Litografya Matbaası, 1284/1867-1326/1908. 1898-1903 Maârif Nezâreti Salnâmelerinde Antakya Kazasında yer alan medreseler değerlendirilirken bu medreselerin orta öğretim dengi kurumlar olarak düşünülebilir. Bk. Mikail Kolutek-İsa Kalaycı, "Salnamelere Göre Antakya Kazası'nda Eğitim (H. 1316-1326/M. 1898-1908)", Uluslararası Sosyal Araştırmalar Dergisi 12/66 (Ekim 2019), 357-368.

16 Maârif Nezâreti Salnâmeleri'nden Ali Efendi'nin 1317/1899-1319/1901 ve 1321/1903-04 tarihlerinde Zincirli Medresesi'nin müderrisi olduğu anlaşılmaktadır. Salnâme-i Nezâret-i Maârif-i Umumiyye, 1317/1899, 1260-61; Salnâme-i Nezâret-i Maârif-i Umumiyye, 1318/1900, 1260-61; Salnâme-i Nezâret-i Maârif-i Umumiyye, 1319/1901, 538-539; Salnâme-i Nezâret-i Maârif-i Umumiyye, 1321/1903, 463.

17 Burada Âdâb'dan maksat, Osmanlı medrese programında yer alan, araştırma ve münazara ilke ve yöntemlerini konu edinen Âdâbü'l-bahs ve'l-münâzara olmalıdır.

18 BOA. DH. SAİD. İSAM Tasnif Numarası: 1607_02. Daha geniş bilgi için bk. Ömer Korkmaz, "Sicill-i Ahvâl Defterlerine Göre Adana Müftüleri ve Müderrisleri", Al Farabi 6th International Conference on Social Sciences, ed. Hatice Nur Germir (Adana: Farabi Publishing House, 2019), 261-270.

19 1320/1902 tarihli Ankara vilayeti salnamesinde Kayseri sancağında 39 medrese bulunduğu, bu medreselerden yıllık 1500'ü aşkın ilim talebesinin 'âlî ilimleri tahsil ettiği ve yılda 20-30 talebenin tahsilini ikmal edip icâzet aldığı belirtilmektedir. Bk. Salnâme-i Vilayet-i Ankara, Sene 1320, Ankara Vilayet Matbaası, 203. 1318/1900 tarihli Ankara vilayeti salnamesine göre de Kayseri'de 39 medrese bulunmaktadır. Bk. Salnâme-i Vilayet-i Ankara, Sene 1318, 193. 
sene eğitim gördükten sonra Kayseri'ye giderek Gözübüyük Medresesi'nde Hamurculu Osman Efendi'den zikredilen ilimlerin yanı sıra Mantık, Akâid ve Belagat okuması, ${ }^{20}$ İlyas Efendi'nin de aynı ilimleri tahsil ettiğinin başka bir göstergesidir. Nitekim imtihan varakasında Mantık, Akâid ve Belagat ile ilgili sorular da yer almıştır. Hocası da icâzet metninde ona Tefsir, Hadis ve bunlarla ilgili şer'î ilimler, dil/lisân ('ulûm-i âliye) ve felsefî ilimlerle ('ulûmü'l-hikemiyye) ilgili icâzet verdiğini belirtmiştir. Dolayısıyla İlyas Efendi'nin dinî ilimlerle birlikte felsefî/aklî ilimlerde de öğrenim gördüğü anlaşılmaktadır. ${ }^{21}$ Kelâm metinlerinin felsefî ilimlere dair konular da ihtiva ettiğ $\mathrm{i}^{22}$ gerçeğinden hareketle İlyas Efendi'nin felsefî ilimlerle ilgili kimi bilgileri Kelâmla birlikte tahsil ettiği de söylenebilir.

İlyas Efendi, köyündeki (Kötin/Kandilli) Medresesinde talebe okuturken Kânunievvvel 1328/1912-1913'te Dörtyol kazasının Kuzuculu köyüne giderek müderrislik yapmaya başlamıştır. ${ }^{23}$ İmtihanda başarılı olduğu hâlde Arnavut muhacirlerinden Yunus Zühtü Efendi tayin edilmek istenmiştir. Bunun nedeni olarak da İlyas Efendi'yi Dörtyol kadısı Hayreddin b. Arslan'ın istememesidir. Bununla birlikte Dörtyol müftüsü Mustafa Remzi Efendi tarafından Yunus Zühtü Efendi'nin riyakâr bir karaktere sahip olduğu, kadınlara muska yazdığı gibi kadının (nâibin/Hayreddin Efendi'nin) hemşehrisi ve komitelerine hizmetkâr olduğunun açılanması üzerine her iki görüş Adana müftüsü Mehmet Zâhir Efendi tarafından dikkate alınarak İlyas Efendinin Dörtyol müderrisi olması için Meşihat'a izbar edilmiş ve neticede İlyas Efendi Dörtyol müderrisliğinde kalmıştır. İlyas Efendi, Medreselerin lağvedilmesinden sonra Kuzuculu Merkez Câmii'nde imamlığa ve dersler vermeye devam etmiştir. ${ }^{24}$ Müderrislik yapabilmek için tabi tutulduğu imtihan varakası ve icâzet metni dosyasında yer almaktadır.

20 BOA. DH. SAİD. İSAM Tasnif Numarası: 1634_02. Ayrıca bk. Korkmaz, “Sicill-i Ahvâl Defterlerine Göre...”, 261-270.

21 Nitekim Osmanlı kaynaklarında ve bu arada icâzetnâmelerde riyâziyyât, tabiiyyât ve hikemiyyât şekillerinde geçen riyâzî ve tabiî ilimler, aklî ya da felsefî ilimlere bağlı ilimlerdir. Bk. Cevat İzgi, Osmanlı Medreselerinde İlim Riyâzî ve Tabî̀ İlimler (İstanbul: Küre Yayınları, 2019), 113.

22 Şükran Fazlığlu, “Manzûme Fî Tertîb El-Kutub Fî Ulûm ve Osmanlı Medreselerindeki Ders Kitapları"ndan naklen Kevâkib-i seb`a, yaprak 60a.

23 BOA. DH. SAID. İSAM Tasnif Numarası: 1597_02.

24 Sadık Albayrak, Son Devir Osmanlı Uleması (İlmiye Ricalinin Teracim-i Ahvâli) (İstanbul: İBB Kültür İşleri Daire Başkanlığı Yayınları, 1996), 2/229; Abdurrahman Yılmaz, Din Hizmetine Adanmış Ömürler: Kozan, Feke, Saimbeyli ve Tufanbeyli Bölgesinin Manevî Önderleri 1750-1950 (İstanbul: Kitaparası Yayınları, 2021), 75-76. 


\section{2. İcâzet Metnine Dair Mülahazalar}

Medresede öğrenim gören talebenin eğitimlerini tamamladıklarına dair eğitimöğretim ve mesleki yeterlik için gerekli izin ve onayı ifade eden icâzet/nâme, hocanın öğrencisine okuttuğu kitap ve ders(ler)i kendisinden okuduğunu, bunları başkalarına okutabileceğini gösteren belgenin genel adıdır. ${ }^{25}$ Medrese öğrencisi, medrese öğrenimine başladığ1 tarihten itibaren hangi eser(ler)in eğitimini almışsa bunların isimlerinin zikredilmesi suretiyle ders aldığı hocasından bir belge alır ve böylece medrese derslerini tamamlayıp ders verme izni ve yeterliğini içeren bir vesika ile müderrislik, müftülük ya da kadılık yoluna girerdi. ${ }^{26}$ Dolayısıyla icâzet belgelerinin cari olan eğitim sistemi, tedris edilen ilimlerle ilgili hangi eserlerin okutulduğu, kimlerden ders alındığı (ilmin kaynağı) ve bu derslerde takip edilen yöntemler hakkında önemli bilgileri barındırdığı söylenebilir.

İçerik bakımından aralarında küçük farklar olsa da icâzet metinleri çoğunlukla şu unsurlardan oluşmaktadır: İcâzetin başında besmele, Allah'a hamd (hamdele), Hz. Peygamber'e salât ve selâm (salvele), ashâbına dua ve kelime-i şehadetin akabinde konunun; ilmin, âlimin, öğretme ve öğrenmenin, irşâd ve isnadın (ulemâ silsilesinin) önemi vurgulanır. Talebenin ismi (ve ailesiyle ilgili bilgiler) kaydedilerek sahip olduğu nitelikler belirtilir. Hoca kendi ismini belirtip okuttuğu kitap veya kitapları, öğrettiği ilim ve sanatı, verdiği irşâd hizmetini kimden ve ne tür yöntemlerle aldığını serdeder, aşağıdan yukarıya doğru ulemâ silsilesini belirtir; elde ettiği ehliyeti sürdürmesi için talebeye izin verdiğini ifade eder, devrettiği hakkın nasıl kullanacağına dair tavsiyelerde bulunarak kendisine dua etmesini ister. İcâzet, bazen meşhur bir âlimde ve çoğu zaman sahâbe ve en nihayetinde Hz. Peygamber' de biter. Bu şekilde icâzet silsilesi, o ilim dalının en yetkin/otorite imamına ya da ilk esas kaynağına bağlanmış olur. Dinî/naklî ilimlere (hadis, tefsir, fıkıh, tasavvuf) ait icâzetler Hz. Peygamberde, aklî ilimlere dair olanlar ise müessisinde son bulur. İcâzetin sonunda icâzet veren hocayla ilgili bilgilere (isim, künye vs.) yer verilerek veriliş tarihi, hocanın imza veya mührü ile icâzet nihayete erdirilir. ${ }^{27}$

İlyas Efendi'ye ait icâzet metninde de yukarıda belirtilen unsurların çoğunun yer aldığı görülmektedir. Bununla birlikte metinde hocanın okuttuğu kitaplar, icâzet için isnadın

25 Bk. Hüseyin Atay, Osmanlılarda Yüksek Din Ĕ̆itimi (Ankara: Atayy Yayınları, 2018), 131; Uzunçarşıll, Osmanlı Devletinin İmiye Teşkilatı, 75-77.

26 Uzunçarşılı, Osmanlı Devletinin İlmiye Teşkilatı, 75.

27 Uzunçarşıllı, Osmanlı Devletinin İlmiye Teşkilatı, 75; Atay, Osmanlılarda Yüksek Din Ĕ̆itimi, 131-133; Cemil Akpınar, "İcâzet", Türkiye Diyanet Vakfi İslâm Ansiklopedisi (İstanbul: TDV Yayınları, 2003), 21/393-400. 
önemine dair bahis ve kelime-i şehâdet cümlesinin yer almadığı görülmektedir. İlyas Efendi'nin aldığı icâzet umumi ${ }^{28}$ olup Osman Hilmi Efendi'den almıştır. Osman Hilmi Efendi, 1284/1876'da Hâçin kazasının hem müdür nâibi hem de müderrisindendir. ${ }^{29}$ İlyas Efendi'nin Osman Efendi'den aldığı icâzetin ulemâ silsilesi şu şekildedir:

“Osman Efendi, Hâfız Muhammed Emin el-Hulûsî el-Kayserî’den (mevliden ve mevtınen), o el-Hac Muhammed Sâlih Torun el-Kayserî'den (mevliden ve mevtınen), o Hafız Kâsım b. Şeyh el-Hac Mahmûd el-Kayserî'den (mevliden ve mevtınen), o da el-Hac Osman b. Mustafa el-Akşehrî (mevliden, el-Kayserî mevtınen) ve Muhammed Emin el-Hâdimî'den icâzet aldı. el-Hac Osman b. Mustafa el-Akşehrî, el-Hac Ömer el-Harpûtî ve Muhammed Saîd el-Medenî'den icâzet aldı. Onlar/ikisi ve Muhammed Emin el-Hâdimî de babası Muhammed/Mehmed Ebû Saîd el-Hâdimî’den icâzet aldılar. O da müderris olan babası Şeyh Mustafa b. Osman el-Hâdimî'den, o da Kütüb-i Sitteyi Muhammed b. Ahmed etTarsûsî'den, ${ }^{30}$ o Muhammed b. Ali el-Kâmil(î̀)'den, o Hayreddin ed-Deylemî'den, o Ahmed b. Muhammed b. Abdü'l-'Âl'den/Abdülâlâ'dan aldı. Ona da babası Şeyhü'l-İslâm Zekeriya el-Ensârî, ona da (Buhârî şârihi) Şihâbüddîn Ahmed b. Hacer el-Askalânî, ona da (Hidâye sahibi) Burhaneddin İbrahim Tenûhî, ona da Burhâneddîn eş-Şâmî, ona da Allâme Ahmed b. eş-Şı(a)hne, ona da Sirâcüddîn Ebî Abdillâh el-Hüseyin b. el-Mübârek ez-Zebîdî el-Bağdâdî, ona da Ebu'l-Vakt Abdü'l-Evvel b. İsa eş-Şehberî, ona da Ebu'l-Hasan Abdurrahman b. Muhammed ed-Dâvudî, ona da Abdullah b. Ahmed el-Hamevî es-Serahsî, ona da Muhammed b. Yûsuf el-Firebrî/Firberî(?), ona da (Ebû Abdullah) Muhammed b. İsmail elBuhârî icâzet verdi. Buhârî ise Hz. Peygamber'e kadar muttasıl olarak rivayet etmiştir."31

Osman Hilmi Efendi, burada tekrar Ebû Saîd el-Hâdimî’ye dönerek diğer bir icâzet silsilesine yer verir:

“Ebû Saîd el-Hâdimî (öl. 1176/1762), (aklî ve naklî/şer'î ilimleri) Allâme Ahmed elKâzâbâdî/Tokâdî (Kazovalı) (öl. 1163/1750)'den aldı. O da et-Tefsîrî’den Mehmed/Muhammed b. Ahmed ed-Debbâğî es-Sivâsî'den (tefsiriyle meşhur zat), o da

28 Genel icâzetin birinci grubunda öğrenciye okutulan derslerin neler olduğu ve hangi tür kitapların okutulduğu, icâzeti veren müderrisin aldığı derslerin ve okuduğu hocaların isimleri gibi detay sayılabilecek bilgiler yer alırken diğer grupta fazla ayrıntıya girmeden aklî ve naklî ilimler ya da âli ve 'âlî ilimler gibi genel ifadelerle tahsil ettiği ilimler belirtilerek icâzetin verildiğine değinilmektedir. Atay, Osmanlllarda Yüksek Din Ĕ̆itimi, 136.

29 Salnâme-i Vilayet-i Haleb, Sene 1284, 67.

30 Bu kişi Kütüb-i Sitte ve bilhassa Buhârî icâzeti almıştır.

31 İcâzet metninde Buhârînnin senedinin Hz. Peygamber'e kadar ulaştığı ifade edilmiş ancak silsilenin devamı getirilmemiştir. 
Mevlânâ Ali el-Gürânî'den, o da Zeynelâbidîn el-Gürânî'den, o da es-Seyyid Abdullah elCüzey/Cezerî'den (?), o da Mevlânâ Ahmed el-Kürdî el-Mücellâ/Müncel'den (?), o da Mevlânâ Mirzâcân eş-Şîrâzî'den, o da Hâce Cemâleddin eş-Şîrâzî̀'den, o da Muhakkik Celâleddin Muhammed b. Es‘ad es-Siddîkî ed-Devvânî'den, o da Muhyiddin elKûşkenârî'den (?), o da eş-Şerîf Allâme Muhammed b. Ali el-Cürcânî'den, o da Mevlânâ Mübârek Şâh el-Kazvînî'den, o da Kutbuddîn er-Râzî́den, o da allâme Şîrâzî́'den, o da (Ömer) el-Kâtib el-Kazvînî’den, o da İmâm Fahreddin er-Râzî (öl. 606/1210)'den, o da İmâm Hüccetü'l-İslâm el-Gazzâlî (öl. 505/1111)'den, o da İmâmü'l-Harameyn Şeyh Abdülmelik b. Abdillâh b. Yûsuf [el-Cüveynî (öl. 478/1085)]'den, o da (Nişabur Nizâmiye Medresesi müderrislerinden) babası Abdullah b. Yûsuf en-Nîsâbûrî (öl. 438/1047)'den, o da Ebû Tayyib b. Muhammed b. Süleyman es-Sa'lûkî'den (muhtemelen fıkıh tahsili), o da Ebû İshak İbrahim el-Mervezî (öl. 340/951)'den, o da Ebü'l-Abbas Ahmed b. Ömer es-Süreyc/î elBağdâdî (öl. 306/918)'den, o da Ebü'l-Kâsım Osmân'dan, o da Ebû İbrahim İsmail'den, o da Ebû Abdillâh Muhammed b. İdris eş-Şâfi‘î (öl. 204/820)'den, o da İmâm Muhammed b. Hasan eş-Şeybânî (öl. 189/804)'den, o da Ebû Hanîfe Nu'man b. Sâbit (öl. 150/767)'ten, o da Hammâd b. Ebû Süleyman (öl. 120/737)'dan, o da İbrahim b. Yezîd en-Nehâî (öl. 95/713)'den, o da Alkame b. Kays en-Nehâî (öl. 62/681), Ebû Abdurrahman el-Esved b. Zeyd (öl. 86/705) ve Ebû Abdurrahman Abdullah b. Habib (öl. 70/689)'den aldı/öğrendi. ${ }^{32}$ Bunların ilk ikisi Abdullah b. Mes ‘ûd (öl. 32/652)'dan, üçüncüsü Ali b. Ebû Tâlib (öl. 40/661)’den, onlar da Hz. Peygamber' den aldilar."

İsnad silsilesinden sonra icâzeti veren hocanın öğrencisine tavsiyeleri, dua, tarih ve mühür ile sona ermektedir. Bu bölümde bilhassa Allah'tan sakınma (takvâ) konusu vurgulanmakta, konu âyetlerle desteklenmektedir. Iffet, istikâmet, haşyet, rızâa, tevazu, ra'fet, şefkat ve merhamet vurgulanan ve aslında hocanın öğrencisinden edinmesini istediği diğer hasletlerdir. Sonunda ise icâzet veren hocanın ismi ve künyesi bulunmaktadır ki bütün icâzetlerde konuşan icâzeti alan değil, icâzeti veren müderris ya da hocanın kendisidir. ${ }^{33}$ Burada icâzeti veren hoca/müderris (mücîz) kendisini Hâfız Osman el-Hilmî b. eş-Şeyh Ahmed el-Kayserî el-Mâtüridî (i'tikâden) el-Hanefî ('amelen) olarak tanitmaktadır. İcâzetin veriliş tarihi ise 1323-1905/1906 olarak kaydedilmektedir. Böylece eğitimini hem mektep hem

\footnotetext{
32 İcâzet metninde "tilmîz" kelimesi geçmekte olup ifade, “öğrencisi oldu” ya da "o da falan kişinin öğrencisidir" şeklindedir.

33 Atay, Osmanlılarda Yüksek Din Ĕ̆itimi, 145.
} 
de medresede tamamlayan İlyas Efendi'nin 32-33 yaşlarında icâzet aldığıı, 39-40 yaşlarında ise müderrislik için yapılan imtihanda başarılı olduğu anlaşılmaktadır. İlyas Efendi, icâzet aldığı tarihten Dörtyol/Kuzuculu müderrisliği için girdiği imtihana kadarki süreçte de müderrislik ve imamlık yaptığı anlaşılmaktadır. ${ }^{34}$

İslâm eğitim-öğretim geleneği incelendiğinde sadece belli bilgilerin aktarıldığı (tedrîs, ta`lîm, öğretim) bir yapının öngörülmediği, eğitim sisteminin edeb, ahlâk ve terbiye boyutuyla bir bütün teşkil etmesinin hedeflendiği söylenebilir. Nitekim edeb/te'dîb ve terbiye, bu bütünlüğe göndermede bulunan kavramlardır. İcâzetin geneli ve özellikle son kısmı düşünüldüğünde tedrîs, ta‘lîm, edeb/te'dîb ve terbiyenin birlikte olduğu, bilgi-eylem bütünlüğünün vurgulandığı; ahlâkın/ahlâklanmanın, eğitim sürecinin bir parçası olmaktan çok bu sürecin bütününe sirayet ettiği ve eğitimden ayrı düşünülmediği şeklinde bir anlayıştan söz edilebilir.

İlyas Efendi'ye ait icâzet metnindeki silsile, aklî ve naklî ilimleri kendisinde mezcetmiş Ebû Saîd el-Hâdimî’ye, Fahreddin er-Râzî'den yukarıya doğru Gazzâlî kanalıyla devam ederken ondan aşağıya Seyyid Şerîf Cürcânî’nin öğrencilerinden Es‘ad ed-Devvânî yoluyla devam ederek Hz. Peygamber'de son bulmuştur. Buradan hareketle vahiy ve sünnet merkezli bir ilim anlayışı ortaya konduğu söylenebilir. Bu durum icâzetnâmelerde görülen genel ve ortak bir özellik olup söz konusu dinî ilimler olunca böyle bir anlayışın normal karşılanması gerektiği ileri sürülebilir. Bununla birlikte icâzet metninde ilimler, temelde aklî ve naklî olarak belirtilmektedir.

Silsilede yer alan Ebû Saîd el-Hâdimî, medrese geleneğinde seçkin âlimlerden olmanın yanı sıra aynı zamanda tasavvufî (Nakşibendî) yönüyle de temayüz etmiştir. Nitekim Osman Efendi'nin İlyas Efendi'ye verdiği icâzetin son kısminda el-Hâdimî'nin nasihat içerikli bir risale yazdığından bahsetmekte ve "Hatm-i Hâcegân" 35 ifadesine bizzat yer vermektedir. Hatm-i Hâcegân'dan -tespit edilebildiği kadar- ilk kez Abdullah Salâhî elUşşâkî (öl. 1196/1782) İzhâr-ı Esrâr-ı Nihân ez Envâr-ı Hatm-i Hâcegân isimli eserinde bahsetmiştir. Eserde hatme, üç farklı şekilde uygulanmaktadır. Birinci düzende sırasıyla besmele ile beraber 7 kez Fâtiha, 100 salavât, 79 besmeleyle birlikte İnşirâh, 1001 defa

34 Bk. Albayrak, Son Devir Osmanlı Uleması, 2/229.

35 Hatm-i Hâcegân; Nakşibendiyye tarikatının bilhassa Hâlidiyye kolunda uygulanan bir zikir şekli olup başında ve sonunda okunan Fâtiha suresi Kur'ân'ın özeti ve hatmedilmesi gibi sayıldığından bu isim verilmiştir. Bk. Reşat Öngören, "Hatm-i Hâcegân", Türkiye Diyanet Vakfı İslâm Ansiklopedisi (İstanbul: TDV Yayınları, 1997), 16/476-477. 
besmeleyle beraber İhlâs, tekrar 100 salavât ve 7 kez besmeleyle birlikte Fâtiha okunup dua edilir. ${ }^{36}$ İlyas Efendi'nin icâzet metninde de 7 Fâtiha, 100 salavât-1 şerîfe, 79 İnşirâh, 1001 İhlâs, sonrasında yine 7 Fâtiha ve 100 salavâtın okunması tavsiye edilmektedir. Bu bakımdan icâzet, bir yönüyle tasavvuf icâzeti olarak da kabul edilebilir.

Bunun dışında İlyas Efendi'nin ilmi (bilhassa fıkıh usulü ve kelâm), Fahreddin erRâzî geleneğine bağlı ulemâdan aldığı ileri sürülebilir. İcâzetteki ulemâ silsilesinden hareketle Osmanlı dinî düşüncesine ve dolayısıyla eğitim-öğretim sistemine, Hanefî̀Mâtüridî düşüncesini benimsemiş Fahreddin er-Râzî ekolünün ağırlıklı olarak etkilediği görüşü̈ ${ }^{37}$ teyit edilebilir. ${ }^{38}$ Nitekim Osmanlı Devletinde beylik ya da kuruluş döneminden itibaren merkezi yönetim, Müslüman tebaa içindeki dinî ve mezhebî yapıyı her zaman göz önünde bulundurup her cemaatin kendi içinde kendi hayatına -genel düzeni sarsmamak kaydıyla- izin vermekte, ancak kendisi dinî politikasını Müslüman çoğunluğun mezhebi olan Hanefiliğge dayandırmaktaydı. ${ }^{39}$ İlyas Efendi'nin icâzet aldığ 1 Osman Hilmi Efendi de kendisini Mâtüridî-Hanefî olarak tanıtmaktadır. Yine İlyas Efendi'nin okuduğu Dürerü'lHükkâm ve Mülteka'l-Ebhur Hanefî fıkhına ait kitaplardır. Bununla birlikte Şerhü'l-Akâid, Eş‘arî ekole mensup Sa'deddîn et-Teftâzânî (öl. 792/1390)'nin Mâtürîdî Necmeddin Ömer b. Muhammed en-Nesefî (öl. 537/1142)'nin Akâid'ine yazdı̆̆ı meşhur şerhlerdendir. Şerhte Teftâzânî, Nesefî'yi yer yer eleştirerek Eş‘arîliği savunsa da kimi zaman Mâtürîdî düşünceyi benimsemiştir. $\mathrm{Bu}$ da Eş'arî kelâm âlimlerinin etkilerinin Osmanlı medreselerinde devam ettiği ve bu etkide Teftâzânî gibi âlimlerin etkili olduğunu göstermesi açısından önemlidir. Burada dikkati çeken diğer bir husus ise icâzet senedleri arasındaki benzerliklerdir. ${ }^{40}$

\section{3. İmtihan Varakası}

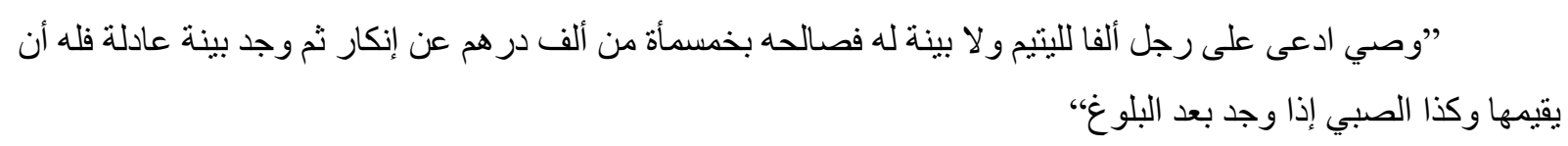

36 Daha detaylı bilgi için bk. Mehmet Saki Çakır, "Hatm-i Hâcegân ve Hâlidilik'teki Uygulanan Örnekleri," İhya Uluslararası İslam Araştırmaları Dergisi (IHYA) 5/2 (Güz 2019), 488-505; Öngören, "Hatm-i Hâcegân", 16/476477.

37 Uzunçarşılı, Osmanlı Devletinin İlmiye Teşkilatı, 75-77.

38 Talip Ayar, "Bir Osmanlı Müderrisinin İcâzetnâmesi ve Tarihî Kaynak Değeri Üzerine Bazı Mülahazalar", Turkish Studies 9/1 (Winter 2014), 43-62.

39 Ahmet Yaşar Ocak, “Osmanlı İmparatorluğu’nda Din, 14.-17. Yüzyıllar”, ed. Ahmet Yaşar Ocak, İslam'ın Ayak İzleri: Osmanlı Dönemi (İstanbul: Kitap Yayınevi, 2011), 92.

40 Örneğin bk. Ayar, “Bir Osmanlı Müderrisinin İcâzetnâmesi ve Tarihî Kaynak Değeri Üzerine Bazı Mülahazalar", 43-62; İrfan Görkaş, "Bolvadinli Ahmet Fevzi Efendi ve Konyalı Mehmet Vehbi'nin İcazetnamesi", Türkiyat Araştırmaları Dergisi 26 (2009). 


\section{S.1.}

\section{Manas1}

C.1.

Bir vasî bir racül üzerine yetim içün bin dirhem iddia eylese kendi içün beyyine bulunmadığı hâlde müdde‘â aleyhin inkârından nâşî beş yüz dirhem ile dahi musâleha olsa sonra beyyine-i makbûle bulsa vasî içün o beyyine ikâme edüp bini tamamen almak vardır. Sabî mezkûr dahi bâliğ oldukdan sonra beyyine-i âdile bulunduğu vakitte vasî gibi beyyine ikâme edüp tamamen bini almak vardır.

\section{S.2.}

(ادعى) ne kelime ve hangi babdan masdarı nedir ve masdarın tarifi, sülâsî kelimelerinde kıyâsî masdar var mıdır? tafsîlen beyânı

\section{C.2.}

Fiil-i mâzî, ifti‘âlden, iddi'â', ismü'l-hadesi'l-cârî ale’l-fi'ili, mimli olursa kıyâsî bazen şâzdır mimsiz olursa semâ‘î.

\section{S.3.}

tبعد البلوغ) kelimesinde kaç ihtimal vardır ve bu terkibde hangisi bulunmuştur ve bu ihtimâlât diğer zurûfa şâmil midir?

\section{C.3.}

Üç ihtimal var. Muzâfun ileyh mezkûr olursa mu'rab zarfiyet üzere mansûb ve eğer muzâfun ileyh mahzûf olur, menvî olursa zamme üzere mebnî olur ve eğer muzâfun ileyh mensî olursa tenvînle mu'rab olur. Ve sâ'ir zarflardan قبل kelimesi dahi böyledir.

\section{S.?}

(ادعى) kelimesinin isnâd olunduğu zamîrin istitârı vâcib midir câiz midir? İstitâr-1 vâcibin tarifi ve bulunduğu mahallerin ta'dâdı

\section{C.?}

İstitârı câizdir. Vâcibin tarifi ما لا يجوز إبر ازهو لا يسند عامله إلا إليه vâcibin mahalli: mazinin gayrı mütekellim ve muhâtablarda, emir manasına olan isim fiilde kühul (?) meselesinin gayrı ism-i tafdîlde amellerinin şartı bulunmayan ism-i fâil, ilm-i mef'ûl, sıfat-1 müşebbehe, zarf-1 müstakar ve bunların manasına olanlarda, ism-i fâ'il ism-i mef'ûlün mutlak tesniye ve cemi‘ sâlimlerinde.

S.4. 
(ادعى) kelimesinin vasîye isnâdı hakikat midir mecaz mıdır? İsnâd kaç kısımdır. Hakikat ve mecazın tarifleriyle beraber isnâdın aksâmının tarif ve ta ‘dâdı

C.4.

İsnâd hakikat. İsnâd iki kısımdır: Hakikat ve mecaz. İsnâd-1 hakikî: " إثبات الثىى لما هو

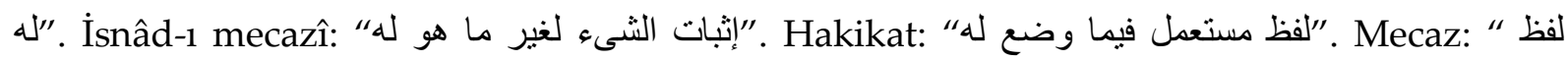
"مستعمل في غير ما وضع له لعلاقة مع عدم جواز إر ادته

S.5.

kelimesinin mef'ûlüyle îrâdındaki nükte nedir ve mef'ûlsüz zikr olunur ise kezâlik bundaki nükte nedir? İzah ediniz.

C.5.

Fiili mef‘ûl ile îrâdında nükte fiil-i lâzım failsiz tam olmadığı gibi bu fiil-i müte'addîde mef'ûle mukârin ve mülâbis olmadıkça faide müfîd olmaz. Mef‘ûlsüz zikr olunur ise garaz yalnız fiilin failden sudûru maksûd olup müte'allika ta'alluku murâd olmadı̆̆ıdır.

S.6.

Mutlak vaz' neye derler ve kaç kısımdır? ث’nin vaz'ı nasıl vaz'dandır? Beyan ediniz. C.6.

Mutlak vaz، “تخصيص شىء لشىء بحيث منى أطلق أو أحس الثىء الأول فهم الثناني". Vaz“ iki kısımdır: Şahsî, nev'î. ث’nin vaz'1 vaz'-1 şahsîdir.

S.7.

(ثم وجد)' ke olimesinin terâhî manasında isti'mâli nerededir. Bu babda İmam A'zam rahimehullâh ile İmâmeyn hazerâtı beyninde olan ihtilâfın esbâbı nedir. Zevc zevce-i gayr-i mevtû'esine “" dediği vakit İmam A‘zam’a göre kaç ve İmâmeyn hazerâtına göre kaç talâk vâki‘ olur?

C.7.

İmam A'zam’a göre terâhî fi't-tekellüm, İmâmeyn'e göre terâhî fi'l-hüküm manasında müsta 'meldir. Bu ihtilâfa binâ'en kavl-i mezkûrda İmam A'zam'a göre bir talâk lâ ilâ aded (?) vâki` olur mâ ba‘dı lağv olur. İmâmeyn’e göre küllîsi mu'allak olur. Şartın vücûduna mütevakkıf olur. 
S.8.

nasıl kaziyyedir. Mutlak kaziyye neye derler. Nisbet ve mevzû‘ i'tibârıyla kaç kısımdır ve bu kaziyye bu aksâmın içinden hangi kısmında dâhildir. Dâhil olduğu kısmın tarifiyle izahı ve bu kaziyyenin cevab ve cezası nedir?

C.8.

Kaziyye-i şartıyyedir. Mutlak kaziyye "قول يصح أن يقال لقائله إنه صـادق فيه أو كاذب فيه". Kaziyye nisbet itibariyle iki kısımdır: Mûcibe, sâlibe. Tarifleri: "ما ", "ما يكون الحكم فيها بالإيقاع "يكون الحكم فيها بالانتزاع". Mevzû“ itibariyle kavl-i meşhûrda üç: Mahsûsa, mahsûra, mühmele.

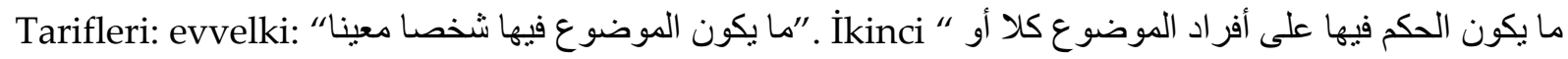

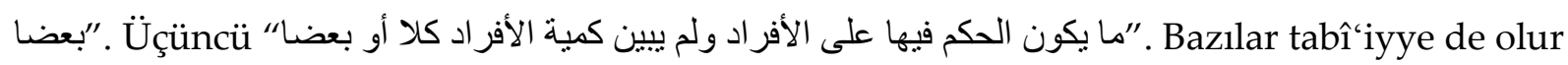
dediler. Tarifi: “ما لا يكون الحكم فيها على أفراد الموضوع". Bu kaziyye mühmeledir. Cevabı mahzûf ”فله أن يقيمها“.

S.9.

"ادعى" fiildir. Hâlik-i ef‘âl kimdir ve bu babda Ehl-i Sünnet ile Mutezile'nin edillesi nedir ve ef‘âlullâhdan garaz ve hikmet nedir? İmanın ziyade ve noksan olmamasına karşı "ayet-i kerîmesini nasil tevil edersiniz?

C.9.

Hâlik cenâb-1 Allah'tır. Ehl-i Sünnet'in delili “"الله خالق كل شى" emsâli ayetler.

Garaz nedir? “بفئل عما يفل يسل

İmanın ziyade ve noksan olmamasına karşu bu ayet-i kerîme ile murâd Ashâb'dır. Mü'menün bihde ziyadedir.

Fî 9 Kânûn-i Evvel sene 328.

Dörtyol kazası Kuzuculu Müderrisi İlyas.

İşbu imtihân huzurumuzda ve nezâretimizde icra edildiği cihetle işbu mahalle şerh ve imza olundu. Fî 9 Kânûn-i Evvel sene (1)328.

Müsevvid (imza) Müderris (imza) Müftü (imza) Naip (imza)

Numara 135

Mûmâ-ileyh Hacı İlyas Efendi mahkeme-i şer'iyyede komisyon-i mahsûs marifetiyle tertib edilen es'ile varakasına lazım gelen ecvibeyi huzurumuzda tahrîr eylediği varaka-i imtihâniyye komisyonumuzca tedkîk olunup mûmâ-ileyh Hacı İlyas Efendi'nin Dörtyol kazası müderrisliğine ehliyet ve liyakati olduğu ve mûmâ-ileyhin hüsn-i ahlâk sahibi dahi 
bulunduğu cihetle işbu mahalle şerhle imza eyleriz. Fî 10 Kânûn-i Evvel (Aralık) sene (1)3281912/1913.

Müsevvid (mühür) Müderris (mühür) Müftü (mühür) Naip (mühür)

\section{Varakayla İlgili Değerlendirmeler}

Klasik dönem müderrislik imtihanları, -yöntem ve muhtevada birtakım değişiklikler/farklılıklar olsa da- Osmanlının son dönemlerine kadar devam etmiştir. Örneğin 1910'da yayınlanan Medâris-i İmiye Nizâmnâmesi'nin 37. maddesine göre müderrislik için imtihan şartı koşulmuştur. Bu maddeye göre müderris adayları Ulûm-ı Edebiyye-i Arabiyye, Ulûm-ı Tabi'iyye ve Riyâziyye, Mantık, Fenn-i Menâzir/Münâzara, Kelâm,

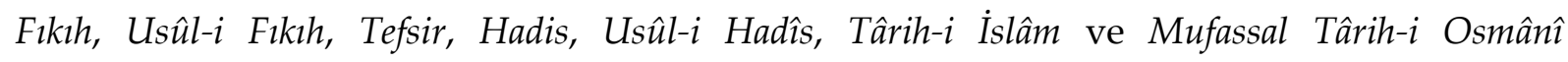
derslerinden imtihana tabi tutulacaklardır. ${ }^{41} 1910$ Medâris-i İlmiye Nizâmnâmesi'nden sonra taşra medreselerini düzenlemeye dair bir nizâmnâme daha hazırlanmıştı. Bu nizâmnâmeye göre de elinde belgesi (icâzet/nâme) olan her müderrisin ataması yapılamayacak ve seçici ilmî bir heyet tarafından ehliyetli olanlar belirlenerek görevlendirilecekti. ${ }^{42}$ İlyas Efendi örnekliğinde görüldüğü üzere medresede görev almak için icâzet/nâme ile birlikte yapılacak imtihanda başarılı olmak da gerekmektedir.

Aldığ1 icâzet ve yapılacak imtihan neticesinde ehliyet ve liyakat sahibi olduğuna hükmedilmesi durumunda kişi, başta medresede dinî ilimlerin tedrisi olmak üzere herhangi bir din görevliliğinde istihdam edilmiştir. İcâzetnâme alan kimsenin imtihan neticesinde ehliyetli ve liyakat sahibi olduğuna ise bir müsevvid ${ }^{43}$, bir müderris, bir müftü ve bir naipten oluşan bir heyet tarafından karar verilmiştir. Karar verilirken ehliyet, liyakat ve ahlâklı olmanın temel ölçütlerden kabul edildiği görülmektedir. Nitekim müderriste aranan nitelikler vakfiyelerde genel olarak "ehl-i ilim ve sâhib-i fazilet, sâhib-i haysiyet olmak" şeklinde ifade edilmiştir. ${ }^{44}$ İlyas Efendi 19. yüzyılın sonları, 20. yüzyılın başlarında yaşadığından bu istihdamın müderrislik ve din hizmetleriyle sınırlandığı söylenebilir. Zira Batı tarzı yeni eğitim kurumlarının açılması, bir yönüyle istihdam alanını da sınırlamıştır. İlyas Efendi'ye ait imtihan varakası aynı zamanda son dönem medrese mezunlarının

41 Atay, Osmanlılarda Yüksek Din Ĕ̆itimi, 301.

42 Medaris-i İmiye Nizâmnâmesi, 5.

43 Müsevvid, resmî dairelerde ve çoğunlukla mektubî ve tahrîrât kalemlerinde müsvedde kaleme alan kâtiplerle ilgili kullanılan bir kavramdır. Bk. Pakalın, Osmanlı Tarih Deyimleri ve Terimleri Sözlü̆̆̈̈, 2/629.

44 Mehmet İpşirli, "Müderris", (Osmanlılar'da), Türkiye Diyanet Vakfı İslâm Ansiklopedisi (İstanbul: TDV Yayınları, 2006), 31/468-470. 
müderrislik için hangi derslerden ne tür sorularla muhatap olduklarını göstermesi açısından da önemlidir.

İmtihân varakasında belli bir alandan değil, birçok alandan sorular yer almıştır. Medâris-i İlmiye Nizâmnâmesinin zeylinde de taşra medreseleri için Mutavvel adlı eserle birlikte Sarf, Nahiv, Mantık, Me'ânî, Beyân, Fıkıh, Fıkıh Usulü ve Kelâm'dan beşer mühim soru sorulacağı, bu sorulara $25^{\prime}$ ten az olmamak koşuluyla doğru cevap verilmesi ve seçilmiş bir heyet tarafından tedris için seçildiğini doğrulayan ehliyet şehâdetnâmesi alınması gerektiği belirtilmiştir. ${ }^{45}$ Müderris İlyas Efendi için yapılan sınavda ise on ${ }^{46}$ soru sorulduğu, soruların Arap Dili ve Belă̆atı, Fıkıh, Kelâm ve Mantık'ta yoğunlaştığı görülmektedir. Dolayısıyla Nizâmnâmede belirtilen alanlardan sorular sorulmakla birlikte soru sayısında farklılık gözlenmektedir. Bu durum, Nizâmnâmenin (mali kaynaksızlık ve savaş gibi sebeplerle) uygulanması ve ülke sathına yaygınlaştırılması noktasında bazı aksaklıkların yaşandığını, 1slahatların çoğunlukla İstanbul'la/İstanbul medreseleriyle sınırlı kaldığını gösteren karinelerden biri sayılabilir.

İmtihan varakasının aynı zamanda müfredatın ${ }^{47}$ tümünü kapsamadığ1 görülmektedir. Zira örneğin imtihanda Hadis, Hadis Usulü ve Tefsire dair sorulara doğrudan yer verilmemiştir. Buradan hareketle bu dönemde düzenlenen imtihanların tüm medreseleri kuşatıcı bir şekilde değil, farklı medrese seviyeleri için ayrı ayrı olarak düzenlendiği çıkarımında bulunulabilir. Yine İlyas Efendi'nin öğrenim gördüğü dönemde müfredatta henüz yer almayan Hendese, Cebir, Kimya, Tarih ve Coğrafya gibi müspet/modern ilimlerle ilgili sorular da doğal olarak imtihan risalesinde yer almamıştır. Dahası medrese mezunları, çoğunlukla müderrislik ve din görevliliği alanında istihdam edildiklerinden imtihanda ekseriyetle dinî ilimlere yönelik sorular yer almıştır. Bu durum, İlyas Efendi'nin medresede dinî ilimler ile Arap Diline yönelik dersler verdiğini gösterse de özellikli olarak hangi ders(leri)i okuttuğu muallaklığını korumaktadır.

Tefsir, Hadis, Fıkıh, Kelâm, Akâid, Mantık, Sarf, Nahiv ve Belagat gibi derslerin belirli kitaplardan okutulmasının ve imtihanın bu dersler merkeze alınarak yapılmasının bir alanda

45 Medaris-i İlmiye Nizâmnâmesi, 5.

46 İmtihan varakasında numaralı olarak dokuz sorunun yer aldığı, ancak üçten dörde geçerken arada numarasız bir sorunun daha olduğu görülmektedir. Bu nedenle soru sayısı dokuz değil, on olmalıdır.

47 Burada "müfredat" derken Osmanlı döneminde devlet tarafından zorunlu kılınan ve bütün medreselerde riayet edilmesi istenen bir programdan değil, çeşitli ilmî alanlarda okunan/okutulan ders kitapları ile temel metinlerin kastedildiğinin altı çizilmelidir. Daha geniş bilgi için bk. Şükran Fazlıŏlu, “Osmanlı Medrese Müfredatına Dair Çalışmalar: Nereden Nereye?" TALID 6/12 (2008). 
derinleşmeye engel olduğu ileri sürülebilir. Ayrıca Mantık'la ilgili soruya verilen cevaptan hareketle metin merkezliliğin ve ezber yönteminin medreselerin son dönemine kadar devam ettiği iddia edilebilir. Bununla birlikte metinlerden hareketle okutulan eserlerin sözü edilen ilimlerin çerçevesini çizen eserler olduğu da söylenebilir. ${ }^{48}$ Daha önce her medreseye bir müderris tayin edilirken 20. yüzyıl başlarında mektep şeklinde medreseler kurulunca her derse bir müderris atama sistemi benimsenmiştir. ${ }^{49}$ Ancak İlyas Efendi'nin görevli olarak atandığı medresede hangi dersi/dersleri okuttuğu, bir ya da birden fazla müderrisin olup olmadığı belgede açık değildir. Bunun dışında tâlibin müderrislik imtihanında sadece okunan kitaplar ya da tedris edilen ilimlerden değil, imtihandan önce edindiği müderrislik deneyimi ile atanması düşünülen medresede okutacağı kitaplarla/ilimlerle ilgili hâkimiyetini ölçmeye dair soruların da yer alabileceği gerçeği ${ }^{50}$ gözden uzak tutulmamalıdır. Zira İlyas Efendi, Tefsir ve Hadis gibi ilimleri tahsil etmişken ve bu durum icâzet metninde açıkça belirtilmişken bunlarla ilgili sorular imtihan varakasında yer almamıştır.

وصي ادعى على رجل ألفا لليتيم ولا بينة له فصالحه بخمسمأة من ألف در هم عن إنكار ثم “ Birinci soruda ibaresinin anlamı sorulmaktadır. Bu soruda İlyas Efendi'den fıkıh kitaplarında geçen bir meseleyi tercüme etmesi istenmektedir ki ilgili ibareyi şu şekilde tercüme etmiştir: “Bir yetimin/sabînin vasisi, yetimin bir adamdan 1000 lira (dirhem) alacağı olduğunu iddia etse ancak delili bulunmadığı için davalı ile inkâr etmesi nedeniyle 500 lira üzerine sulh etse, daha sonra geçerli bir delil bulsa, bu delili ikame ederek vasinin 1000 lirayı tamamen alma hakkı vardır. Aynı şekilde adı geçen sabî de baliğ olduktan sonra makbul bir delil bulunduğu zaman vasi gibi bu delil ile alacağı olduğunu ispat ederek 1000 lirayı alabilir."

Görüldüğü üzere birinci soru, İlyas Efendi'nin hem Arapça hem de Fıkıh bilgisini ölçmektedir. Ancak sonraki soruların tamamı da bu Arapça ibare ile ilgilidir. Sonraki sorularda ibaredeki kelimelerin ve farklı birçok ilimle bağlantılı meselelerin tahlili istenmektedir.

İkinci soru Sarfi ilgilendiren birkaç sorudan oluşmaktadır. Bu soruda "ادعى" (idde“â) fiilinin ne tür bir kelime olduğu, hangi baptan geldiği ve masdarının ne olduğu, ardından

48 Bununa ilgili bk. Ayşe Zişan Furat, "Klasik Dönem Osmanlı Medreselerinde Okutulan Eserler," ed. Fuat Aydın vd., Osmanlı Medreseleri: Ĕ̆itim, Yönetim ve Finans (İstanbul: Mahya Yayıncılık, 2018).

49 İpşirli, "Müderris", (Osmanlılar'da), 31/468-470.

50 Bk. Furat, “Fetih Sonrasında Osmanlı Eğitim Anlayışının Şekillenişi”, 11-31. 
masdarın tarif edilmesi istenerek sülâsî kelimelerde kıyasî masdarın olup olmadığ1 sorulmaktadır. İlyas Efendi, ilgili kelimenin mazi fiil olduğunu, ifti‘âl babından geldiğini ve masdarının “ادعاء" (iddi'â) olduğunu söylemektedir. Masdarı "fiil üzerinde gerçekleşen hadesin/işin/eylemin ismidir" şeklinde tarif ederek sülâsî kelimelerde mimli masdar olursa şâz olarak kıyasî masdarının gelebileceğini, ancak mimsiz masdar olursa masdarının semâ‘î olduğunu belirtmektedir. Bütün bunlarla ilgili İzzeddin ez-Zencânî (öl. 660/1262[?])'nin Osmanlı medreselerinde okutulan temel metinlerden olan ve aynı konudaki el-Emsile, Binâ'ü'l-ef'âl, el-Makșûd ve Merâhu'l-ervâh ile birlikte "Sarf Cümlesi" diye anılan el-'Izzî fi'ttasrîflet-Tasrîfü'l-'izzî ya da et-Tasrîf eseri ile Sa'deddin et-Teftâzânî (öl. 792/1390)'nin buna yazdığı Şerhu Tasrîfi'z-Zencânî şerhinde detaylı bilgiler yer almaktadır. ${ }^{51}$

Üçüncü soru Nahiv ile ilgilidir. “بعد البلوغ" terkibinde bulunan “بعد" kelimesinde Nahiv açısından kaç ihtimalin bulunduğu ve mevcut ibarede hangi ihtimalin, ayrıca bu ihtimallerin diğer hangi zarflarda geçerli olduğu sorulmaktadır. İlyas Efendi burada üç ihtimalin bulunduğunu belirtmektedir: Birinci ihtimal, “بعد" kelimesinin muzâfun ileyhi zikredilmesi durumunda mu'rab ve "بعد" kelimesinin -burada olduğu gibi- mansub olacağ1 yönündedir. İkinci ihtimalde muzâfun ileyh hazfedilmiş olur ancak zihinde mevcut (menvî) olursa bu durumda "بعد" kelimesi zamme üzerine mebni olur. Üçüncü ihtimalde ise muzâfun ileyhi unutulmuş (mensî) olur ve bu durumda da "بعد" kelimesi tenvin ile irab alır. Diğer zarflardan “قبل" kelimesi de böyledir. ${ }^{52}$

Numaranın olmadığı soruda fiil-fâil ilişkisi ve bununla ilgili olarak zamirin gizli olmasının zorunluluğu (vâcib) ve câizliği, zamirin gizli gelmesinin anlamı ve hangi durumlarda gizli gelmesinin vâcib olduğu meselesi sorulmaktadır. İlyas Efendi, soruyu “kühul (sürme) meselesi” üzerinden cevaplamaktadır. Kühul meselesi şu şekildedir: ما ر أيثُ (Gözündeki sürmesi Zeyd'in gözündeki sürmeden daha güzel olan hiçbir adam görmedim). Örnekteki الكُحْلُ kelimesi, ism-i tafdîl olan آَحسنَ lafzının fâili olup ism-i tafdîlin fâil-i zahirinde amel edebilmesi gerekli olan beş şartı kendinde

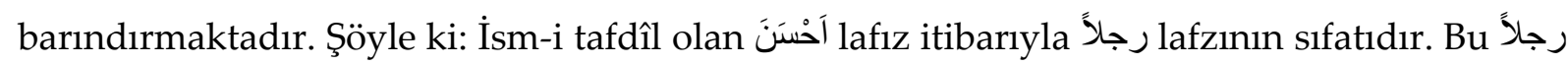
lafzı mâ cerâ 'aleyh'tir (üzerine hüküm cereyan eden). Her ne kadar lafız itibarıyla اَََْْنَ lafzı

51 İzzeddin ez-Zencânî, et-Tasrîfü'l-'İzî (Beyrut: Dârü'l-Minhâc, 2008), 52 vd.; Sa'deddin et-Teftâzânî, Şerhu tasrîfi'l-'Izzî (Beyrut: Dârü'l-Minhâc, 2011), 83 vd. Ayrica bk. Sa'deddin et-Teftâzânî, Şerhu's-Sa'd 'alâ tasrîfi'zZencânî (İstanbul: Salah Bilici Kitapevi, ts.), 30, 80.

52 Bk. Abdurrahman-1 Câmî, el-Fevâ'idü'z-ziyâ'iyye 'alâ metni'l-kâfiye fi'n-nahv/Şerhu Molla Câmî (Beyrut: y.y., 2009), 2/102-103. 
kelimesinin sıfatı olsa da mana itibariyle الكُحْلُ kelimesinin sıfatıdır. Zira güzellik haddizatında الكُحْلُ yani sürme ile kaimdir. Müteallik olan الكُحْلُ yärme adamın gözü ile Zeyd'in gözü arasında müşterek olup (ikisinin de gözüne sürme çekmesi) adamın gözüne taalluku itibarıyla mufaddal olmuştur (üstün kılınmıştır). İşte bu üçüncü şarttır. الكُحْلُ Zeyd'in gözüne taalluku itibarıyla "mufaddalun aleyh"tir (kendisine üstün kılınmış) ki bu da dördüncü şarttır. İsm-i tafdîl olan اَحَْنَ lafzı menfîdir. Yani cümlenin başında bir mâ-i nâfiye (ما) vardır. İşte bu da beşinci şarttır. İsm-i tafdîl, belirtilen şartlarda fâil alırken mefulu bih (belirtili nesne) almaz. ${ }^{53}$

Dördüncü (?) soru Meân̂̂ ile ilgilidir. "ادعى" kelimesinin vasiye isnadının hakikat mi mecaz mı olduğu sorulmaktadır. Ayrıca isnadın kaç kısım olduğunun hakikat ve mecazın tarifleriyle birlikte yazılması istenmektedir. İlyas Efendi, “ادعى" kelimesinin vasiye isnadının hakikat olduğunu belirtmektedir. İsnadın hakikî ve mecazî olmak üzere iki kısım olduğunu söyleyerek tanımlarını yapmaktadır. Hakikî isnadı "bir şeyi (fiili) 'mâ hüve leh'ine ispat ve isnad etmektir" şeklinde, mecazî isnadı da "bir şeyi (fiili) 'mâ hüve leh'inin dişında bir şeye isnad etmektir" şeklinde tanımlayarak klasik kitaplardaki tanımlara yer vermektedir. Fiilin gerçek failine isnad edilmesine hakikî isnad, gerçek failine değil de vuku bulduğu zamana, mekâna veya fâilin bir öğesine isnad edilmesine de mecazî isnad denir. İlyas Efendi, hakikat ve mecazı da aynı şekilde tarif etmektedir. Hakikat "vaz olunduğu (gerçek) anlamda kullanılan lafızdır." Mecaz ise “Bir ilgi ve karîne ile vaz olunduğu anlam dışında kullanılan lafızdır." İlyas Efendi'ye isnad ve kısımları, hakikat ve mecazla ilgili yöneltilen sorular ve onun bunlara verdiği cevaplar el-Mutavvel adlı eserde genişçe izah edilmektedir. ${ }^{54}$

Beşinci soruda "وجد" kelimesinin mefûlüyle birlikte zikredilmesinin nedeni sorulmaktadır. Ayrıca fiil mefûlsüz zikredildiği zaman buradaki inceliğin ne olduğunu açıklaması istenmektedir. İlyas Efendi'ye göre fiilin mefûlüyle birlikte zikredilmesinin sebebi bu gibi müteaddî fiillerin mefûlü ile zikredilmediğinde fâide hâsıl olmamasıdır. Nasıl ki

53 Konuyla ilgili İbn Mâlik et-Tâ̂̀'nin (öl. 672/1274) Arapçaya dair el-Elfiyye adlı eseri üzerine Celâlüddîn Süyûtî́nin (öl. 911/1505) yazdığ1 ve hâlen doğu medreselerinde ders kitabı olarak okutulan Behcetü'l-merdiyye fì şerhi'l-Elfiyye adlı şerh ile İlyas Efendi'nin de okuduğu Mollâ Câmî̀ye bakılabilir. Celâlüddîn Süyûtî, Behcetü'l-merdiyye ma'a haşiyetihi et-tahkîkâtü'l-vefiyye li- Molla Sâlih el-Ğursî (Diyarbakır: y.y., 2011), 355-356; Mollâ Câmî, el-Macmûatü'n-nûriyye el-müştemil 'alâ sitteti kutubin fi'n-Nahv (Abdurrahman-1 Câmî, el-Fevâ'idü'zziyâ'iyye/Mollâ Câmî, nşr. Dâru Nûri's-Sabâh (Midyat: y.y., 2010), 2/204-205, 417-420.

54 Bk. Sa'deddin et-Teftâzânî, el-Mutavvel/Şerhu telhîs miftâhu'l-'ulûm, thk. Abdülhamîd Hindâvî (Beyrut: Dârü'lKütübi'l-İlmiyye, 2013). Ayrica Ebû Ya'kûb es-Sekkâkî (öl. 626/1229)'nin Miftâhu'l-'ulûm'unun üçüncü bölümüne (meânî ve beyân kısmına) Hatîb el-Kazvînî (öl. 739/1338)'nin yazdı̆̆ı Telhîșü'l-Miftâh'ın Sa'deddin et-Teftâzânî (öl. 792/1390) tarafından yapılan muhtasar şerhi Muhtasarü'l-Meânî adlı eserde de konuyla ilgili bilgiler mevcuttur. Örneğin bk. et-Teftazânî, Muhtasarü'l-me’ânî (İstanbul: Salah Bilici Kitapevi, ts.), 43-56. 
lazım fiiller failsiz tam olmuyorsa bu fiiller de mef'ûlsüz müfîd olmaz. Ancak mefûlsüz zikrediliyorsa orada fiilin sadece failden sadır olduğu maksud olup bir mefûle bağlanması murad edilmez. Gerek fiilin kısımları (lazimî-müteaddî) gerekse fiilin ne zaman müfid olacağ1 ile ilgili et-Teftâzânî'ye ait Şerhu tasrîfi'l-'izzî ile Abdurrahman-1 Câmî̀ye ait Mollâ Câmî adlı eserlerin ilgili yerlerine bakılabilir.

Altıncı soru $V a z$ 'ilmiyle ilgilidir. Mutlak olarak vaz'ın ne demek olduğu ve kaç kısım olduğu sorulmaktadır. Ayrıca "ثم" kelimesinin hangi kısım vaz‘a girdiğinin beyan edilmesi istenmektedir. İlyas Efendi mutlak vaz‘1 şöyle tarif etmektedir: “ilk şey mutlak olarak zikredildiğinde ya da hissettirildiğinde ikincisinin anlaşılacağı şekilde bir şeyin diğer bir şeye tahsis edilmesidir." Vaz'ın şahsî ve nev“î olmak üzere iki kısım olduğunu belirten İlyas Efendi, “ث”nin vaz‘ının şahsî vaz‘ olduğunu ifade etmektedir. Adudüddin el-Îcî (öl. 756/1355)'nin er-Risâletü'l-vaż'iyye/Risâle fi'l- vaż' adlı eseriyle bunun şerhlerinden olan Şerhü'l-'allâme Ebi'l-Leys es-Semerkandî 'ala'r-risâleti'l-'Adudiyye li'l-İmâm Adudüddin el-Îcî̀de konuyla ilgili bilgiler mevcut olup ${ }^{55}$ İlyas Efendi'nin mezkûr eserleri okumuş olabileceği ihtimal dâhilindedir.

Yedinci soru Fıkıh sorusudur. “" kelimesinin hangi hususta terâhî (erteleme, sonraya bırakma) manasında kullanıldığı sorulmaktadır. Özellikle İmam Ebû Hanîfe (öl. 150/767) ile İmâm Ebû Yûsuf (öl. 182/798) ve İmâm Hasan b. Muhammed eş-Şeybânî (öl. 189/805) arasındaki ihtilafın sebebinin zikredilmesi istenmektedir. Bu bağlamda koca, kendisiyle ilişkiye girmediği karısına "أنت طالق ثم طالق ثم طالق إن دخلت الدار (Eğer eve girersen boşsun, sonra boşsun, sonra boşsun)" dediğinde adı geçen imamlara göre kaç talakın geçerli olacağı sorulmaktadır. İlyas Efendi “ث” kelimesinin Ebû Hanife’ye göre konuşmada terâhî anlamına geldiğini söylemektedir. İmâmeyn'e göre ise “ث” hükümde terâhî anlamina gelir. Bu ihtilafa göre yukarıdaki söz söylendiğinde Ebû Hanife'ye göre bir talak gerçekleşir ve sonraki lafızlar lağvolur. İmâmeyn'e göre ise üç talak şarta bağlanmış olur ve şart (eve girme) gerçekleştiğinde üç talak da gerçekleşmiş olur.

Sekizinci soru Mantık sorusudur. “إذا وجد"nin nasıl bir önerme olduğu, mutlak önermenin tarifi ve nisbet ve mevzu itibarıyla kaç kısım olduğu sorulmaktadır. Ayrıca metindeki önermenin hangi kısma girdiği sorularak bu kısım önermenin tarif edilerek açıklanması istenmektedir. Ayrıca metindeki önermenin cevap ve cezası sorulmaktadır. İlyas

55 Örneğin bk. Ebü'l-Leys es-Semerkandî, Şerhü'l-'allâme Ebi'l-Leys es-Semerkandî 'ala'r-risâleti'l-'Adudiyye li'l-İmâm Adudüddin el-Î́̂̂̀ (İstanbul: Hâşemî Yayınevi, 2011), 64-71. 
Efendi “"إذا وجدn ş şartlı önerme olduğunu söylemektedir. Mutlak önermeyi “söyleyene o, sözünde doğru söyleyicidir ya da yalan söyleyicidir demek sahih olan sözdür" şeklinde tarif ederek nisbet itibarıla önermenin mûcibe (olumlu) ve salibe (olumsuz) olmak üzere iki kısma ayrıldığını belirtmektedir. Dolayısıyla İlyas Efendî’nin Osmanlı medreselerinde Mantıkla ilgili yaygın bir şekilde okutulan Esîrüddin el-Ebherî (öl. 663/1265[?])'nin Îsâğ $\bar{u} c \hat{\imath}$ fi'l-mantık adlı eserinden hareketle cevaplar verdiği anlaşılmaktadır. Nitekim onun yaptığı (mutlak) önerme tanımı aynıyla sözü edilen eserde yer almaktadır. ${ }^{56}$

Dokuzuncu soru Kelâm sorusudur. Bu soruda "ادعى" bir fiil olduğu belirtilerek fiillerin yaratıcısının kim olduğu sorulmaktadır. Bu bağlamda Ehl-i Sünnet ile Mu'tezile'nin delillerinin ve Allah'ın fiillerindeki garaz/amaç ve hikmetin ne olduğu sorulmaktadır. Ayrıca imanda artma ve eksilme olmuyorsa "و إذا تليت عليهم آياته زادتهم إيمانا، ayetinin İlyas Efendi tarafından nasıl tevil edildiğinin beyan edilmesi istenmektedir. İlyas Efendi fiillerin yaratıcısının Allah olduğunu söyleyerek Ehl-i Sünnet'in delilinin " gibi ayetler olduğunu ifade etmektedir. "يسئل عما يفعل لا" ayetinin Allah'ın fiillerindeki garaz ve hikmeti açıkladığını belirtmekte ve imanda artma ve eksilme olmadığını, ilgili ayette muhatabın ashâb olduğunu söylemektedir. Ayrıca imanın kendisinde değil, iman edilecek hususlarda artma olduğunu ifade etmektedir. İlgili bilgiler için Teftazânî́nin Şerhü'l-Akâid ile Şerhü'l Makâsıd adlı eserleri başta olmak üzere kelâmla ilgili medreselerde okutulan diğer kitaplara

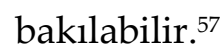

56 Bk. Esîrüddin el-Ebherî, Îsấḡucî fi'l-mantık/Mantık İsagoci Tercümesi \& Mantık Terimleri Sözlü̆üü, çev. Talha Alp (İstanbul: Yasin Yayınevi, 2013), 22. Bunun dışında konuyla ilgili Esîrüddin el-Ebherî̀nin Îsâgūucî'sine yazılan meşhur şerhlerden olan ve Osmanlı medreselerinde son dönemlere kadar okutulan Mollâ Fenârî (öl. 834/1431)'nin el-Fevấidü'l-Fenâriyye ve Şerhu'ş-şemsiyye'si, Fevấid'e Kul (Kavil) Ahmed/Ahmed b. Muhammed b. Hıdır tarafından yazılan hâşiye (Kul/Kavl-i Ahmed) ile Sirâceddin el-Urmevî (öl. 682/1284)'nin Metâlli'u'lenvâr' ına da bakılabilir.

57 Örneğin bk. Sa'deddin et-Teftâzânî, el-Macmûatü's-Seniyye 'alâ şerhi'l-'akâidi'n-Nesefiyye (Midyat: Dâru Nûri'sSabâh, 2012), 368-415. 


\section{Sonuç}

Tanzimat Dönemiyle başlayan eğitimde Batı etkisi ve medrese dışında kurulan yeni eğitim kurumlarıyla eğitimde modernleşme, eğitim sisteminde olduğu gibi medrese mezunlarının istihdamında da birtakım değişmelere/daralmalara neden olmuştur. Zira adli, idari, askeri vs. görevliler, yeni açılan eğitim kurumlarıyla karşılanırken medresenin istihdam alanı çoğunlukla din hizmetlerini ifa edecek görevlilerin ve müderris gibi medrese elemanının yetiştirilmesine hasredilmiştir. Nitekim İlyas Efendi de hem imamlık hem de müderrislik görevi üstlenmiştir. Dolayısıyla 19. yüzyılın son çeyreği ile 20. yüzyılın ilk çeyreğinde de medreselerin imam, vaiz ve müftülük gibi din hizmetlerinde ihtiyaç duyulan personelin ve müderrislik gibi eğitici kadro için ihtiyaç duyulan görevlilerin istihdam alanlarına hazırlanma hedefi güttügü anlaşılmaktadır.

Medrese eğitimini tamamlayıp ilmî ehliyete sahip olduğu tescillenerek icâzet alan talebelerin müderris olarak atanabilmeleri için medresede okudukları/okutacakları ilimlerden imtihan şartı konulmuştur. Dolayısıyla müderris olmak, icâzetle birlikte imtihandan başarılı olmayı da gerekmektedir. Başka tabirle ilmî bir heyetin huzurunda kişinin müderrisliğe ehliyetli ve liyakatli olduğuna hükmedilmesi lazımdır. Bunun yanında müderris olarak atanacak kimsede görevinde istenen verimi karşılamak amacıyla alan bilgisi ve yeterliliği ile ahlâkî güzelliğin de arandığı görülmektedir.

İlyas Efendi'nin tahsil hayatı, icâzet metni ve imtihan varakası incelendiğinde Tefsir ve Hadis hariç- öğrenim gördüğü ilimlerden imtihana tabi tutulduğu; imtihanda Tefsir, Hadis ve Hadis Usulü gibi ilimlerle ilgili de doğrudan soruların yer almadiğı anlaşılmaktadır. İncelediğimiz belgede İlyas Efendi'nin hangi alan(lar)da ders verdiğiyle ilgili net bir bilgi bulunmamakla birlikte icâzet ve imtihan varakasından hareketle öncelikle Fıkıh ve Kelâm gibi dinî ilimlerle Arap Dili ve Belagatine (Sarf, Nahiv, Beyân, Me’ânî vs.) yönelik dersler verdiği ileri sürülebilir.

Okutulan eserler ve istihdamla ilgili uygulamalar göz önüne alındığında taşradaki medreselerin merkezdeki benzerlerinden ayırmanın mümkün olamayacağ 
sonucuna varılabilir. Ancak -her ne kadar kurumsal değil, şahıs ve metin merkezli bir eğitim anlayışı hâkim olsa da- kaza, kasaba ve bilhassa köylerdeki medreselerin çoğunlukla aşağı ve orta derecede eğitim veren kurumlar olduğu, her âlimin/müderrisin yönelimine ve ilmî birikimine göre metin tercihinde bulunabileceği ihtimali de gözden uzak tutulmamalıdır. 


\section{Kaynakça}

Abdurrahman-1 Câmî. el-Fevấ'idü'z-ziyâ'iyye 'alâ metni'l-kâfiye fi'n-nahv/Şerhu Molla Câmî. 2 Cilt. Beyrut: y.y., 2009.

Ahmed Cevdet Paşa. Târîh-i Cevdet. 12 Cilt. Dersaâdet: Matbaa-i Osmâniye, 1301/1884.

Akpınar, Cemil. "İcâzet". Türkiye Diyanet Vakfi İslâm Ansiklopedisi. 21/393-400. İstanbul: TDV Yayınları, 2003.

Albayrak, Sadık, Son Devir Osmanlı Uleması (İlmiye Ricalinin Teracim-i Ahvâli) I-V. İstanbul: İBB Kültür İşleri Daire Başkanlığı Yayınları, 1996.

Atay, Hüseyin, Osmanlılarda Yüksek Din Eğitimi. Ankara: Atayy Yayınları, 2. Basım, 2018.

Ayar, Talip, "Bir Osmanlı Müderrisinin İcâzetnâmesi ve Tarihî Kaynak Değeri Üzerine Bazı Mülahazalar". Turkish Studies 9/1 (Winter 2014), 43-62.

BOA. DH. SAIDD. İSAM Tasnif Numarası: 1607_02.

BOA. DH. SAİD. İSAM Tasnif Numarası: 1634_02.

BOA. DH. SAİD. İSAM Tasnif Numarası: 1597_02.

Çakır, Mehmet Saki. “Hatm-i Hâcegân ve Hâlidilik'teki Uygulanan Örnekleri”. İhya Uluslararası İslam Araştırmaları Dergisi (IHYA) 15/2 (Güz 2019), 488-505.

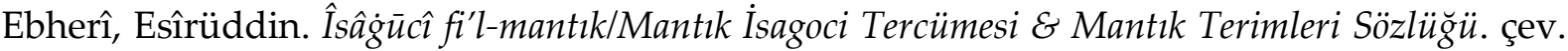
Talha Alp. İstanbul: Yasin Yayınevi, 2013.

Ergün, Mustafa. "II. Meşrutiyet Döneminde Medreselerin Durumu ve Islah Çalışmaları”. Ankara Üniversitesi Dil ve Tarih-Coğrafya Fakültesi Dergisi 30/1-2 (1979/1982), 59-89.

Fazlıoğlu, Şükran. "Manzûme Fî Tertîb El-Kutub Fî Ulûm ve Osmanlı Medreselerindeki Ders Kitapları". Değerler Ĕ̆itimi Dergisi 1/1 (2003), 97-110.

Fazlıŏlu, Şükran. “Osmanlı Medrese Müfredatına Dair Çalışmalar: Nereden Nereye?” TALID 6/12 (2008), 593-609.

Furat, Ayşe Zişan. "Fetih Sonrasında Osmanlı Eğitim Anlayışının Şekillenişi: Klasik Dönem Müderrislik İmtihanları". Osmanlı'da İlim ve Fikir Dünyası: İstanbul'un Fethinden Süleymaniye Medreselerinin Kuruluşuna Kadar. ed. Ömer Mahir Alper, Müstakim Arıcı. 11-31. İstanbul: Klasik Yayınları, 2015.

Furat, Ayşe Zişan. "Klasik Dönem Osmanlı Medreselerinde Okutulan Eserler". Osmanlı Medreseleri: Ĕ̆itim, Yönetim ve Finans. 741-762. ed. Fuat Aydın vd. İstanbul: Mahya Yayıncilık, 2018.

Görkaş, İrfan. "Bolvadinli Ahmet Fevzi Efendi ve Konyalı Mehmet Vehbi'nin İcazetnamesi”. Türkiyat Araştırmaları Dergisi 26 (2009), 247-263.

İzgi, Cevat. Osmanlı Medreselerinde İlim Riyâzî ve Tabî̀ İlimler. İstanbul: Küre Yayınları, 2019.

Kolutek, Mikail - Kalaycı, İsa. “Salnamelere Göre Antakya Kazası'nda Eğitim (H. 13161326/M. 1898-1908)". Uluslararası Sosyal Araştırmalar Dergisi 12/66 (Ekim 2019), 357368.

Korkmaz, Ömer. "Sicill-i Ahvâl Defterlerine Göre Adana Müftüleri ve Müderrisleri". Al Farabi 6th International Conference on Social Sciences. ed. Hatice Nur Germir. 261-270. Adana: Farabi Publishing House, 2019.

Köymen, Mehmet Altay. Büyük Selçuklu Imparatorluğu Tarihi. 3 Cilt. Ankara: TTK Basımevi, 1992.

Medaris-i İlmiye Nizâmnâmesine Zeyl Olarak Tanzim Olunan Taşra Medâris-i Nizâmnâmesi (TMN). İstanbul: Matbaa-i Amire, 1326/1908.

Mollâ Câmî. el-Macmûatü'n-nûriyye el-müştemil 'alâ sitteti kutubin fi'n-Nahv (Abdurrahman-ı Câmî, el-Fevâ'idü'z-ziyấ'iyye/Mollâ Câmî). nşr. Dâru Nûri's-Sabâh. Midyat, y.y., 2010. 
İpşirli, Mehmet. "Medrese". (Osmanlı Dönemi). Türkiye Diyanet Vakfı İslâm Ansiklopedisi. 28/327-333. Ankara: TDV Yayınları, 2003.

İpşirli, Mehmet. "Mülâzemet". Türkiye Diyanet Vakfi İslâm Ansiklopedisi. 31/537-539. İstanbul: TDV Yayınları, 2006.

İpşirli, Mehmet. "Müderris". (Osmanlılar'da). Türkiye Diyanet Vakfi İslâm Ansiklopedisi. 31/468-470. İstanbul: TDV Yayınları, 2006.

Ocak, Ahmet Yaşar. “Osmanlı İmparatorluğu'nda Din, 14.-17. Yüzyıllar”. ed. Ahmet Yaşar Ocak. İslam'ın Ayak İzleri: Osmanlı Dönemi. 84-147. İstanbul: Kitap Yayınevi, 2011.

Ölmez, Adem. “II. Meşrutiyet Devrinde Osmanlı Medreselerinde Reform Çabaları ve Merkezileşme". Vakıflar Dergisi 41 (Haziran 2014), 127-140.

Öngören, Reşat. “Hatm-i Hâcegân”. Türkiye Diyanet Vakfı İslâm Ansiklopedisi. 16/476-477. İstanbul: TDV Yayınları, 1997.

Pakalın, Mehmet Zeki. Osmanlı Tarih Deyimleri ve Terimleri Sözlüğü. 3 Cilt. İstanbul: MEB Basımevi, 1993.

Salnâme-i Nezâret-i Maârif-i Umumiyye. İstanbul: Matbaa-i Amire, 1317/1899.

Salnâme-i Nezâret-i Maârif-i Umumiyye. İstanbul: Matbaa-i Amire, 1318/1900.

Salnâme-i Nezâret-i Maârif-i Umumiyye. İstanbul: Matbaa-i Amire, 1319/1901.

Salnâme-i Nezâret-i Maârif-i Umumiyye. İstanbul: Matbaa-i Amire, 1321/1903.

Salnâme-i Vilayet-i Adana. Adana: Matbaa-i Vilâyet-i Adana, 1299/1881, 1308/1891, 1309/1892, 1312/1894, 1318/1900.

Salnâme-i Vilayet-i Haleb. Haleb/Suriye: Haleb Vilayeti Litografya Matbaası, 1284/18671326/1908.

Salnâme-i Vilayet-i Ankara. Ankara: Ankara Vilayet Matbaası, 1318/1900.

Salnâme-i Vilayet-i Ankara. Ankara: Ankara Vilayet Matbaası, 1320/1902.

Sarıkaya, Yaşar. "II. Meşrutiyet ve Medreseler: Geleneksel Bir Kurumun Modernleşme Sürecinde Var Olma Mücadelesi". Dîvân Disiplinlerarası Çalışmalar Dergisi 13/25 (2008), 37-73.

Semerkandî, Ebü'l-Leys. Şerhü'l-'allâme Ebi'l-Leys es-Semerkandî 'ala'r-risâleti'l-'Adudiyye li'lİmâm Adudüddin el-Îcî. İstanbul: Hâşemî Yayınevi, 2011.

Süyûtî, Celâlüddîn. Behcetü'l-merdiyye ma'a haşiyetihi et-tahkîkâtü'l-vefiyye li-Molla Sâlih elĞursî. Diyarbakır: y.y., 2011.

Teftâzânî, Sa'deddin. Şerhu tasrîfi'l-'İzzî. Beyrut: Dârü'l-Minhâc, 2011.

Teftâzânî, Sa'deddin. Şerhu's-Sa'd 'alâ tasrîfi'z-Zencânî. İstanbul: Salah Bilici Kitapevi, ts.

Teftâzânî, Sa'deddin. Muhtasarü'l-me'ânî. İstanbul: Salah Bilici Kitapevi, ts.

Teftâzânî, Sa'deddin. el-Macmûatü's-seniyye 'alâ şerhi'l-'akâidi'n-Nesefiyye. Midyat: Dâru Nûri's-Sabâh, 2012.

Teftâzânî, Sa'deddin. el-Mutavvel/Şerhu telhîs miftâhu'l-'ulûm. thk. Abdülhamîd Hindâvî. Beyrut: Dârü'l-Kütübi'l-İlmiyye, 2013.

Uzunçarşılı, İsmail Hakkı. Osmanlı Devletinin İlmiye Teşkilâtı. Ankara: TTK Basımevi, 1988.

Yılmaz, Abdurrahman. Din Hizmetine Adanmış Ömürler: Kozan, Feke, Saimbeyli ve Tufanbeyli Bölgesinin Manevî Önderleri 1750-1950. İstanbul: Kitaparası Yayınları, 2021.

Zencânî, İzzeddin. et-Tasrîfü'l-'İzzî. Beyrut: Dârü'l-Minhâc, 2008.

Zengin, Zeki Salih. II. Meşrutiyette Medreseler ve Din Eğitimi. Ankara: Akçă̆ Yayınları, 2002.

Zengin, Zeki Salih. II. Abdülhamit Dönemi Örgün Eğitim Kurumlarında Din Ĕ̆itimi ve Öğretimi (1876-1908). Adana: Baki Kitabevi, 2003.

Zengin, Zeki Salih. Tanzimat Dönemi Osmanlı Örgün Eğitim Kurumlarında Din Eğitimi ve Öğretimi (1839-1876). İstanbul: MEB Yayınları, 2004. 